\title{
UWE JENS LORNSEN OG CHRISTIAN PAULSEN
}

FRA DET BEGYNDENDE POLITISKE OG

NATIONALE TØBRUDS DAGE I DANMARK FOR 100 AAR SIDEN

AF

G. WORSØE SGHMIDT

CAND. MAG., DUBORGSKOLEN, FLENSBORG

*

\section{UWE JENS LORNSEN}

$\mathrm{H}$ undredaarsdagene for Uwe Jens Lornsens Fremtræden i Tiden omkring ved I. November I830, gik i Danmark ret ubemærket hen, idet kun Professor K. Fabricius tog dem til Udgangspunkt for nye Synspunkter i en Artikel i Berlingske Tidende ${ }^{1}$, mens hele det Forfatningsrøre, som Lornsen i saa høj Grad havde været med til at fremkalde, overhovedet først i Magister Hans Jensens Værk om De danske Stænderforsamlingers Historie, hvoraf I. Dels I. Halvbind udkom 28. Maj i 83I, er blevet gjort til Genstand for en sammenfattende, om end for Hertugdømmernes Vedkommende langtfra udtømmende Behandling - hvad der naturligvis heller ikke kan siges at ligge inden for dette Værks Plan at give ${ }^{2}$.

I Danmark tilhører U.J. Lornsen aabenbart en fjern og afbleget Fortid; men paa den Plads, hvor Kampen for og imod hans nationalpolitiske Ideer stod (og staar), er han ikke glemt. Ønsker man et kraftigt Vidnesbyrd om, i hvor høj Grad hans Gerning og hans Tanker endnu lever i moderne slesvigholstensk Bevidsthed, saa behøver man kun at lægge Mærke til, hvorledes Hundredaarsmindet om denne Pioner for Slesvigholstenismen, Slesvig-Holstens „Provinshelgen “ med „Martyrglorien" 3 om sine krusede Lokker, i hans Hjemstavn er blevet

${ }^{1}$ K. Fabricius: Et Hundredaarsminde. Berlingske Tidende, $1 / 11$ 1930, jvf. samme Forfatter: Et nyt Hundredaarsminde. Berl. Tid. 29/5 1931. ${ }^{2}$ Hans Jensen: De danske Stænderforsamlingers Historie I830-I848, I, Kbh. (1931). (Især I. Afsnit, S. 73-138.) ${ }^{3}$ R. Usingers spottende Ord i hans Kritik af K. Jansens Fremstilling, Zeitschrift, Bd. 4. (1873), S. 176. Jvf. A. Fr. U. L. Thomsen: Lewer duad üs Slaw! [Itzehoe] I893, S. 27. 
fejret, ikke blot med Festtaler ${ }^{1}$ og Skuespil ${ }^{2}$, til hans Ere, men lige saa fuldt med Udgivelse af værdifuldt Kildemateriale til Oplysning om hans Liv og Virksomhed, saa vel som med kritiske Vurderinger af hans Personlighed, hans Optræden og hans Betydning for det dansk-tyske Mellemværendes Udvikling fra de Dage, da han paa saa afgørende Maade greb ind deri, og til nu.

Allerede i $19 \mathrm{r} 5$ var vor Viden om hans Karakter og hans politiske Anskuelser blevet betydelig forøget gennem Landsbibliotekar Dr. Volquart Pauls Udgave af hans Breve til Dahlmanns Svoger, Kielerlægen Franz Hermann Hegewisch, ${ }^{3}$ der fra Novemberdagene 1830 og til Lornsens Død $183^{8}$ paa den smukkeste og mest uegennyttige Maade stod ham bi med Penge, Bøger og den hjerteligste Deltagelse i stort som i smaat. Her ser vi U. J. Lornsen bakse med det historiske Stof, som han med største Ulyst gravede sig igennem, fordi han følte det som en Opgave, der nu engang var lagt hen til ham. Hans mere end almindeligt skarpe Blik for Storpolitikkens Maal og Midler - saa vidt hans Erfaring nu strakte træder overraskende klart frem for os, men tillige med uhyggelig Tydelighed, at denne begavede Mand er syg til Døden, mindre vel paa Grund af legemlig Sygdom end som Følge af nedarvet, sjælelig Belastning.

I Mindeaaret har en lige saa stor og paa sin Vis lige saa værdifuld Samling Breve fra hans Haand i bogstaveligste Forstand set Lyset. Oppe under Taget i hans Fødehjem havde der i mange Herrens Aar staaet en gammel Tønde, fyldt med Breve, som i et Par Menneskealdre havde faaet Lov at hvile fredeligt i deres Gemmested. Først da en ny Husmoder i r 9 Io flyttede ind i Huset, fandt hun under sin Oprydning Tønden, og fra nu af blev det hendes Søndagefter-

1 K. Alnor: Uwe Jens Lornsen, der Lebendige (Marts 1930), i „Der Schleswig-Holsteiner“, 1930, S. 145-149. - H. Hagenah: Uwe Jens Lornsen, der Mann, das Werk, die Wirkung. (15/. 1930), „Die Heimat", Jahrg. 40. (1930), S. 246-25o, 265-270. - H. E. Hoff: Uwe Jens Lornsen zum Gedächtnis ( ${ }^{20} \%$ I 930 ), Anf. Sted, S. $478-481$. - Volquart Pauls: Uwe Jens Lornsen und die schleswig-holsteinische Bewegung. (31/1 1930.) Zeitschrift, Bd. 6o. (193I), S. 436-451. ${ }^{2}$ Paul Leuchsenring: Kämpfer ohne Schwert. Kiel 1930. Ingeborg Andresen: Kanten und Kehren. 3 Volquart Pauls: Uwe Jens Lornsens Briefe an Franz Hermann Hegewisch. Schleswig 1925. - Om Hegewisch selv, se Wilh. Klüwer: Franz Hermann Hegewisch. Nordelbingen IV (1925), S. 368-466. - Paul Richter: Aus der schlesw.-holst. Verfassungs- u. Verwaltungsgeschichte. Zeitschrift, Bd. 58. (1929), S. 449-593, især i Exkurs 2: Fr. H. Hegewisch und der Dänische Staat um 1830, S. 557-579. Jvf. Historisk Tidsskrift, 8. R., I (1907-08), S. 300-306. Jvf. ogsaa Caroline Hegewisch: Auszüge aus ihren Briefen, Kiel I882; og Lotte Hegewisch: Erinnerungen früherer Stunden für Letzte Stunden. Kiel 1892. 
middags Fornøjelse at hente et Bundt af de gulnede Breve med ned og læse om sine afdøde Slægtninges Færd'1.

Her fandt Mellemskolekonrektor Wilh. Jessen fra Vesterland paa Sild de Breve fra Uwe Jens Lornsen til hans Fader Jürgen Jens Lorensen, som han i Forbindelse med Statsarkivraad Dr. G. E. Hoffmann paa saa mønsterværdig en Maade har udgivet og kommenteret ${ }^{2}$. Da de spænder over Aarene I81 I-I837 (fra Lornsen som knap attenaarig bliver „Seminaristelev“ i Tønder Borgerskole til faa Maaneder, før han begaar Selvmord ved Genfersøen), aabner de værdifulde Indblik i hans Oplevelser og Anskuelser under Skolegangen i Tønder, Studenteraarene i Kiel og Jena og Kancellitiden i København, tre Perioder, hvorom vor hidtidige Viden var yderst ringe, saa at hans ældre Biografer: G. P. Hansen, K. Jansen, R. Usinger og Th. Graae $i$ alt væsentligt enten har maattet udfylde Hullerne ved at berette Træk om Tiden, hentede fra andre Kilder, eller ved rent ud sagt at gætte sig frem.

De to Udgivere har imidlertid ikke nøjedes med at fremdrage dette rige Stof. I Tidsskriftet „Der Schleswig-Holsteiner" for I 930 har de trykt et Par andre, hidtil ukendte, Breve fra U. J. Lornsen (til Søsteren Erkel ${ }^{3}$, til de to Professorer i Kiel N. Falck ${ }^{4}$ og A. L. J. Michelsen ${ }^{5}$, samt Lornsens Ansøgning om at blive flyttet fra Friedrichsort til Rendsborg Fæstning ${ }^{6}$ ), og i tre Artikler har Wilh. Jessen gennem Uddrag af Breve givet et meget levende Billede af U. J. Lornsens kraftige og dygtige Fader, der som modig og besindig Kaptajn tjente sig en helt anselig Formue sammen i den blomstrende Handelsperiode? Af mindst lige saa stor Betydning er dog en Samling Kildesteder og Aktstykker til Belysning af U. J. Lornsens Deltagelse i Studenterlivet i Kiel og Jena ${ }^{8}$, som Wilh. Jessen har sammenstillet og ladet trykke i det førnævnte Tidsskrift. Det er først dem, der - i Forbindelse med Lornsens egne Breve samt de mere malende Skildringer, som forskellige, allerede tidligere kendte, Erindringer frembyder, kaster det rette Lys over U. J. Lornsens Studenteraar.

Har disse Brev- og Aktstykkesamlinger saaledes i rigt Maal øget vort Kendskab til Ungdomsaarene som til Tiden efter, at Tæppet, med Lornsens Fængsling, var

1 Wilh. Jessen: Lornsen und seine Biographen. „Der Schleswig-Holsteiner" ${ }^{\prime \prime} 930$, S. 4 16. ${ }^{2}$ Wilh. Jessen - G. E. Hoffmann: Uwe Jens Lornsens Briefe an seinen Vater. Breslau r93o. ${ }^{3}$ Skrevet i „Skovlyst" (ved Kbh.), 14/11 1826. „Der Schleswig-Holsteiner" I 930, S. 330-332. Ved Wilh. Jessen. Friedrichsort, 18/7 183 I. Anf. Sted, S. $3^{87}$. Ved G. E. Hoffmann. ${ }^{5}$ Rendsburg, ${ }^{10} / 12$ 1831. Anf. Sted, S. 338. Ved G. E. Hoffmann. Friedrichsort, 14/10 1831. Anf. Sted, S.389. Ved G. E. Hoffmann. 7 Anf. Sted, S. 133-137, 199-202, 283-287. Ved Wilh. Jessen. 8 Anf. Sted, S. 526-53I. 
faldet for Dramaets mest bevægede Akt, saa er det netop denne Periode, som unægtelig set fra statshistorisk Synspunkt er den interessanteste, vi føres ind $\mathbf{i}$ ved en overordentlig vægtig Afhandling af Arkivdirektør Dr. Paul Richter, Kiel: Aus der schleswig-holsteinischen Verfassungs- und Verwaltungsgeschichte von 1815-1835 ${ }^{1}$. Heri skildres saa vel det (slesvig-)holstenske Forfatningsspørgsmaals Historie til og med Lornsenrøret, saadan som man saa paa det i Regeringskredsene og blandt Embedsmænd og maadeholdne Frihedsvenner i Kiel, som ogsaa de Overvejelser og Forhandlinger, der gik ud paa at skabe Grundlaget for en tredje Instans, en Højesteret, for Hertugdømmerne, ved at skille Administration fra Domsmagt ${ }^{2}$, og som her for første Gang drages frem til grundig Behandling, samt $i$ et yderligere Tillæg den allerede nævnte Læge Fr. H. Hegewisch's ufortrødne Klager til Konge og Kancelli over Administrationens Mangler og Misgreb ${ }^{3}$.

Afhandlingen bygger paa en righoldig Samling Arkivalier, hentede fra: Rigsarkivet i København, Statsarkivet i Kiel dels fra vort tidligere tyske Kancellis Arkiv m. m. og ganske særligt fra den Deputerede i det slesvig-holstenske Kancelli, Etatsraad (senere Kurator for Universitetet i Kiel) Johann Friedrich Jensens efterladte Brevsamling 4 , fra Byarkivet i Kiel og Rigsarkivet i Frankfurt a. M. (den tyske Forbundsdags Arkiv). Som Bilag er aftrykt fuldstændigt: Lornsens Brev til Etatsraad J. Fr. Jensen fra Sild, d. 2. Marts 1829, vedlagt et Par Lægeattester ${ }^{5}$, hans Ansøgning om Landfogedembedet paa Sild ${ }^{6}$, Kancelliets Indstilling ${ }^{7}$ med den meget rosende Omtale af ham samt to Breve til Etatsraad Jensen, et fra Professor N. Falck ${ }^{8}$ og et fra Professor Twesten ${ }^{9}$.

Om Kongens og Regeringens Stilling til Forfatningsrøret har vi allerede tidligere været ret vel underrettede. Der skal her kun ganske kort henvises til K. Jansens Uddrag af en Række Breve vekslede mellem Frederik VI og flere af de ledende Statsmænd og mellem disse indbyrdes, offentliggjort i Zeitschrift, I $894^{10}$. De tilhører den Kancelli-Deputerede J. P. Høpps efterladte Brevsamling. En lignende Samling Breve til og fra Frederik VI er blevet fremdraget af Etatsraad H. R. Hiort-Lorenzen i Sønderjydske Aarbøger I $90{ }^{11}$, og af samme Art er nogle Breve fra Præsidenten i det slesvig-holstenske Kancelli, Grev Otto Moltke, til den holstenske Kansler C. L. v. Brockdorff ${ }^{12}$.

Endvidere har Professor Aage Friis gennem en Samling Breve om „Grev Otto

1 Førnævnte Sted, se Side 49, Note ${ }^{3}$. ${ }^{2}$ Anf. Værk; se især Exkurs I, S. 523-556. ' Anf. Værk se Side 49, Note ${ }^{3}$. A Anf. Værk, S. 450. ' Anf. Værk, S. 580-583. 'Anf. Værk, S. $5^{83}$ f. 7 Anf. Værk, S. $5^{84}$ f. ${ }^{\circ}$ Anf. Værk, S. 586-588. ' Anf. Vark, S. $5^{89}$ f. 10 Bd. 24., S. 193-236. 11 S. 169-229. ${ }^{12}$ Zeitschrift, Bd. 34. (1904), S. 171-177. 
Blome og den Lornsenske Bevægelse 1830 " 1 fremlagt et Bidrag til Forstaaelse saa vel af den holstenske Adels Stilling til Forfatningsbevægelsen som af den udenrigspolitiske Side af Sagen. Først ved Dr. G. E. Hoffmanns Uddrag af den senere Statholder $\mathrm{i}$ den provisoriske Regering, Fritz Reventlous efterladte Brevsamling ${ }^{2}$, kan det dog siges, at vi har faaet nogenlunde fyldig Besked om de højst forskellige Anskuelser, som Ridderskabets Medlemmer og de øvrige Godsejere nærede, baade om Lornsen og om, hvilken Stilling Ridderskabet burde tage til Bevægelsen. Ikke mindst viser disse Breve, at Muligheden for en kraftigere Optræden fra Ridderskabets Side har været til Stede i noget højere Grad, end man tidligere har kunnet regne med.

Paa det udenrigspolitiske Omraade bringer Magister Hans Jensens Bog om „De danske Stænderforsamlingers Historie" en hel Del nyt, omend det fra anden Side hævdes, at Behandlingen og Vurderingen af de diplomatiske Indberetninger ikke er helt fyldestgørende ${ }^{3}$. Ogsaa for Regeringskredsenes Vedkommende er nyt Stof til Belysning af Lornsenrøret her fremdraget fra Arkiverne og sammenarbejdet med det allerede kendte, hvorved især den Betydning, som Landgreven af Hessens og Hertugen af Augustenborgs Breve fik i Retning af at virke ophidsende paa Kongen og gøre ham saa ængstelig, at det slesvig-holstenske Krav om en fælles Forfatning for Hertugdømmerne nær havde faaet Kongens Tilslutning, og at kun Grev O. Moltkes energiske Modstand afværgede det, træder stærkt i Forgrunden ${ }^{4}$. Helt klart kan det dog ikke siges, at Linierne i den holstenske Bevægelse er trukket op. Billedet flimrer lidt.

Hvad nyt byder disse Kilder os da til Forstaaelse af Uwe Jens Lornsens Person og Optræden og til Vurdering af Begivenhedernes Gang i de bevægede Dage i Slutningen af Oktober og Begyndelsen af November 1830 i Kiel.

Forskellige Spørgsmaal melder sig af sig selv for os som for det Slægtled, der oplevede Begivenhederne i 1830 .

Var der inden for det danske Monarki i 1830 en saadan Nød eller en saadan Utilfredshed at spore, at den kunde varsle politisk Storm for Frederik VI.s landsfaderlige Styre? Svaret maa blive et afgjort: Nej!

Det økonomiske Tryk, der i en Aarrække havde hvilet over Erhvervslivet og jo da ganske særligt over Landbruget, viste netop nu Tegn til saa smaat at lette

1 Danske Magazin, 5. R. V (1904), S. 17-39. ' G. E. Hoffmann: Zur Geschichte der Lornsen-Bewegung im Herbst 1830. "Der Schleswig-Holsteiner" 1931, S. 81-84, 103-1 06. ${ }^{3}$ K. Fabricius's ovennævnte Artikel i Berlingske Tidende, 29/5 1931. * Hans Jensen: Anf. Værk, især S. 103-1 10. 
gennem stigende Kornpriser ${ }^{1}$. Misvækst i Marskegnene havde vel fremkaldt ret stor Nød og en Del Bitterhed ${ }^{2}$; men Bønderne besad næppe nok Midler til at gøre sig politisk gældende, og det nødlidende Omraade var ikke større, end at Regeringen ved Toldlettelser og anden Støtte kunde afværge den haardeste Nød ${ }^{3}$. Betegnende nok anede man i de politisk vaagne Kredse i Kiel intet om dette Forhold, før en ung Student, den senere saa kendte Agrarhistoriker Georg Hanssen, i Kieler Correspondenzblatt skildrede Tilstanden blandt Bønderne i Viding Herred og paa Pelworm. Ja, den mest ihærdige Forkæmper for en fri Forfatning, Lægen Fr. Hegewisch, var endda ret fortørnet over, at G. Hanssen kunde foreslaa at bruge de Penge, der samledes ind til et Mindesmærke for Frederik VI. i Anledning af 25. Aarsdagen for Livegenskabets Ophævelse, til Lindring af Nøden blandt Bønderne i de nævnte Egne, mens Frederik VI. selv ikke tøvede med at give Tanken sin Tilslutning; ,thi kun i Vore elskede Undersaatters Hjerter ønske $\mathrm{Vi}$ at reise os et blivende Mindesmærke“ 4 .

Hvor stærk var vel Uviljen mod det enevældige Styre i dette Øjeblik hos det slesvig-holstenske Ridderskab, saa noget nær den eneste Klasse af Befolkningen, der tidligere i Kraft af sin Grundbesiddelse og sine Traditioner havde vovet at handle ud fra en selvstændig politisk Opfattelse?

Heller ikke det lod høre fra sig mere, efter at Forbundsdagen i 1823 havde afvist dets Klage over, at den danske Regering ikke vilde anerkende dets formentlige Ret til at repræsentere den gamle „Landdag“. Da det i særlig Grad var Godsejerne, der led under Landbrugskrisen, og Regeringen i mange Tilfælde havde maattet yde dem økonomisk Støtte ${ }^{5}$, har vel ogsaa dette Forhold bidraget til at dæmpe Oppositionslysten noget. Endnu en Grund, der skulde have bevirket, at Ridderskabet foretrak at stille sig afventende, nævnes i Wit v. Dörrings Pjece:

1 Anf. Værk, S. 71. - Det danske Folks Historie VI A (1928), S. 388-389. ${ }^{2}$ Georg Hanssen: Lebenserinnerungen. Zeitschrift, Bd. 40. (1910), S. 37-41. - Notizen, S. 25. - Sønderjydske Aarbøger 1901, S. 1 75, 212 f. - Zeitschrift, Bd. 24. (1894), S. 205.- Hans Jensen: Anf. Værk, S. 93 f. - Af Schleswig-Holsteinische Anzeigen vom Jahr I83o, Glückstadt, fremgaar det, at der har været talrige Udpantninger og Tvangsauktioner i Marskegnene syd for Tønder og paa Pelworm fra August 1830 og det meste af Efteraaret, især i Slutningen af Oktober og Begyndelsen af November, indtil man i København, opskræmt af Lornsenrøret, gav Ordre til saa vidt muligt at undgaa Tvangsforanstaltninger (jvf. Zeitschrift, Bd. 34. (I g04), S. I72; O. Moltke 16/11 1830 til Kansleren i Holsten, G. L. Brockdorff). $\quad$ ' Zeitschrift, Bd. 24. (1894), S. 196, 198, 202, 206 f. - Sønderjydske Aarbøger, 190 I, S. 182. - Hans Jensen, Anf. Værk, S. 94. Schlesw.-Holst. Anzeigen, Stück 45, $\% 11$ 1 830, ang. midlertidig Ophævelse af Rugtolden. 4 Georg Hanssen: Anf. Sted, S. 39 f. - Sønderj. Aarb. r9or, S. 209. ' Marcus Rubin: Frederik VI's Tid. Kbh. 1895. S. 208-220. 
"Was uns Noth thut" 1 . Den offentlige Mening skal i Følge denne Pjece have anset Kronprinsen, den senere Kong Kristian d. VIII for en „bestemt Modstander af den absolute Regeringsform", men tillige have regnet med, at han holdt et aristokratisk Grundlag for den kommende Forfatningsordning for absolut nødvendigt $^{2}$. Og heri tog man jo vist ikke saa ganske fejl, idet vi nu af hans egne Breve og Dagbogsoptegnelser kan se, at han under Forhandlingerne i Statsraadet om Stænderanordningen har kæmpet kraftigt for at lade Godsejerne og Ridderskabet blive stærkere repræsenteret i Stænderforsamlingerne, end Statsministrene vilde gaa med til ${ }^{3}$. Hvis Ridderskabet da blot roligt ventede de faa Aar, der kunde være tilbage, til Prins Kristian afløste Frederik VI, vilde de kunne faa en Forfatning efter deres Hjertens Ønske, mens de ved at slutte sig til Forfatningsbevægelsen nu blot vilde opnaa at spille Magten i Hænderne paa „den store Masse“, som de saa ned paa4.

Gennem de Reventlouske Breve har vi nu imidlertid faaet fast Grund under Fødderne ved Bedømmelsen af Ridderskabets Stilling i Efteraaret I83o.

Det, de ledende, politisk skolede Mænd inden for Ridderskabet frygter mest af alt, er faktisk, at Regeringen skal gøre Alvor af ,at bage en Stænderforfatning sammen " 5 nu paa dette Tidspunkt. De føler det som en Ulykke, fordi de regner med, at den kun vil komme til at omfatte Holsten ${ }^{6}$, og fordi det nuværende Øjeblik er ugunstigt for Ridderskabet, der er indbyrdes uenigt, og hvis Krav hverken finder Tilslutning hos Regeringen eller hos Folket, men nærmest blot vil vække Fortrydelse hos begge Parter. Nej, Overretsraad, Friherre E. v. Heintze mener, at det rette Tidspunkt til at føre Kravet frem vil først være inde, „naar Folk, der i Kraft af deres personlige Stilling og Sindelag bar Landets sande

1 [Hamburg 183I.] 2 Anf. Værk, S. 6 f. - Den nævnte Pjeceforfatter Wit (genannt) v. Dørring er ganske vist en politisk (og vist ogsaa $i$ andre Retninger) noget upaalidelig Herre. Han er Lornsens samtidige og drager med ham fra Kiel til Jena, hvor han i Kraft af sin ypperlige Begavelse straks kommer til at spille en Rolle og er en af de mest yderliggaaende radikale. Siden slaar han fuldstændig om og beskyldes endda for at have ladet sig bruge som Politispion mod sine tidligere Kammerater. Men en skarp Iagttager er han, og hans Opfattelse af de psykologiske Momenters Indflydelse paa det politiske Omraade gør Indtryk af, at han har en fin Sporsans og en hurtig Opfattelsesevne, der sætter ham i Stand til at dømme klart, naar blot ikke hans egen Forfængelighed er med i Spillet. Jvf. hans egne Memoirer og Pjece. - H. Leo: Anf. Værk, S. I 79 ff. - „Der Schleswig-Holsteiner“, 1930, S. 421 f. ${ }^{3}$ Hans Jensen: Anf. Værk, S. 146, r 79, 205 f. 'Danske Magazin, 5. R. V, S. 39. - Jvf. „Der Schleswig-Holsteiner“, I93I, S. 82. ${ }^{5}$ Overretsraad E. v. Heintze ${ }^{22} / 11$ I830 til Fritz Reventlou. „Der Schleswig-Holsteiner", 1931, S. 83. "Landraad Fr. H. A. von Rumohr 20/11 I830 til Fr. Reventlou, Anf. Sted, S. 82. 
Interesse i Hjertet, var stillet ved Roret eller dog udrustet med saadan Indflydelse, at der af deres Tilkaldelse til Raadslagningerne om en Forfatning lod sig vente en virkelig Effekt ${ }^{\text {«1 }}$.

I øvrigt findes inden for det holstenske Aristokrati alle Anskuelser repræsenteret lige fra den unge G. Moltkes yderst konservativt loyale Standpunkt til det mest højrøstet „demagogiske".

Mens E. v. Heintze er højlig forarget over, at „Kieler Philistrene“ synes at ville optræde paa hele Holstens, ja, endda paa Slesvigs Vegne ${ }^{2}$ gennem deres paatænkte Petition, kunde Fritz Reventlou godt tænke sig at løse Spørgsmaalet om, hvordan man skal kunne faa indgivet Petitioner fra alle interesserede Parter i en uangribelig Form, saaledes, at Ridderskabet lod sig overrække Opfordringer fra de ikke-Reciperede Godsejere, og hvem der ellers vilde petitionere, og traadte frem for Fyrsten med dem ${ }^{3}$.

Fritz Reventlou, der i Sommeren I818 samtidig med Lornsen har studeret i Jena og ivrigt taget Del i Burschenschaftbevægelsen, har aabenbart til en vis Grad taget Lornsen i Forsvar mod de haarde Domme over hans Færd, som flere af hans Standsfæller gav Udtryk for ${ }^{4}$, men lige saa fuldt tager han Afstand fra dem, der aabenlyst koketterer med de „Revolutionære“, ud fra den Betragtning, at det er uforsvarligt at puste til Ilden, men lige saa taabeligt at lukke Øjnene for den Bevægelse, der er i Gang, i Stedet for at prøve at faa det bedst mulige ud af den ${ }^{5}$. Men som det vil ses, ønsker han ingenlunde, at Ridderskabet skal „gribes af den almindelige Svindel ${ }^{6}$ eller prisgive sin Stilling som eneste lovlige Repræsentant for Landet over for Kongen. Hans yngre Broder Ernst Reventlou var derimod villig til at ofre Privilegierne for at overvinde de andre Stænders Mistro til Ridderskabet?

Det lader da til, at Fritz Reventlou og hans nærmeste Venner, som ønskede, at Ridderskabet skulde fore en rolig og velovervejet Politik, har indtaget et formidlende Mellemstandpunkt mellem den loyalt-konservative Fløj paa den ene Side og dem, der var Fyr og Flamme, saa snart der var Mulighed for at gaa angrebsvis til Værks over for Regeringen, paa den anden. Thi at der ogsaa var en hidsig og højrøstet venstre Fløj, som til Tider var lidt svær at bringe til Fornuft og faa til at holde Trit og Retning med de øvrige, skinner tydeligt igennem ${ }^{8}$.

1 Heintzes ovennæunte Brev, Anf. Sted, S. 83. $2 \% / 11$ 1830, Anf. Sted, S. $82 . \quad 319 / 11$ 183o, til Grevinde Charlotte Rantzau; Anf. Sted, S. I04. "Anf. Sted, S. 8I ff. 5 Anf. Sted, S. 103 f. 'Anf. Sted, S. 103. ' Brev til Hertugen af Augustenborg, 6/12 183o. J. H. Gebauer: Christian August von Schleswig-Holstein, Stuttg.-Leipzig 1910, S.62. "Der SchleswigHolsteiner", 1931, S. $103 \mathrm{ff}$. 
Men det fremgaar ogsaa klart, at der var et Stykke Vej fra de stærke Ord og til at handle planmæssigt efter dem.

At et enkelt uroligt Hoved, en Verdensmand som Grev Otto Blome til Salzau ${ }^{1}$ satte Skræk i Frederik VI og en Række af vore Diplomater ved sine meget temperamentsfulde og alt andet end velovervejede Udtalelser om den danske Regering, til hvem der gad høre paa dem, - maaske ogsaa lidt for at nyde Virkningen af sine Ord, naar den genspejledes $i$ et Diplomatansigts noget uofficielle Forfærdelse eller for at lade skinne igennem, hvilke fine og indflydelsesrige Forbindelser han havde - behøver ikke at skuffe os. 14 Dage efter at den frygtede Greve, der havde sat saa mange Penne i Bevægelse, var vendt hjem til sit Gods, var han i fuld Gang med at konspirere, blot ikke mod Konge og Regering, men mod - Ræve og Harer ${ }^{2}$. Saaledes endte det Tilløb til Oprør. Og selv om Blome ganske givet har haft enkelte Meningsfæller blandt den øvrige Højadel, saa veg Størsteparten af dem ængsteligt tilbage for udfordrende Skridt af Skræk for Revolutionerne i Udlandet og af Uvilje mod den hjemlige Forfatningsbevægelses udpræget „demagogiske“ Karakter. Da Ridderskabet, som den førende Stand i Landet, d. 22. Nov. 1830 skulde tage Stilling til Lornsenrøret og Forfatningsspørgsmaalet, faldt der io Stemmer paa C. Moltkes, efter de andres Mening „højst servile“, Forslag til en Adresse, 6 paa det, der til sidst gik af med Sejren og var forfattet af den ledende inden for Ridderskabet, "Verbitter", Grev Chr. Rantzau, Rastorf, og 9 paa et, der var stillet af Fritz Reventlous Svoger, Grev Joseph Baudissin, og som indeholdt bestemt formulerede Ønsker om, at Kongen vilde lade $\mathrm{kgl}$. Kommissærer træde sammen med Deputerede af alle Stænder for at høre Landets Ønsker. I anden Omgang enedes man nu om Rantzaus Forslag, der ganske vist efter Baudissins Mening hverken var Fisk eller „Flæsk“ („nicht Fisch, nicht Fleisch“), og i lidt for høj Grad kunde tydes paa flere Maader, men som han dog trods alt egentlig fandt mere passende end sit eget ${ }^{3}$. Den Adresse, Ridderskabet vedtog d. 22. Nov. 1830, tager da i stærke Vendinger Afstand fra den Lornsenske Bevægelse og vover sig først til Slut frem med et meget forsigtigt formuleret og i den dybeste Frbødighed fremført Ønske om, at Hans Kgl. Majestæt i sin Visdom vil befale at ville høre

1 Danske Magazin, 5. R. V, S. 17 ff. ${ }^{2}$ Anf. Værk, S. 32 (Broderens Ord). 3 Baudissin 25/11 1830 til Fr. Reventlou, „Der Schleswig-Holsteiner“, S. 105. - Grev Rantzau, Breitenburg, der var udsendt af Kongen for at udforske Stemningen, har ikke faaet fat paa alle Nuancer; jvf. Sønderj. Aarb., 1901, S. 201. - C. Moltkes Optræden blev paaskønnet paa højeste Sted; jvf. O. Moltkes Brev til C. L. Brockdorff, 1/12 1830 i Zeitschrift, Bd. 34. (I904), S. 176. 
Landets Ønsker ${ }^{1}$. At Kongen ogsaa var ret veltilfreds med Adressen, er let at forstaa ${ }^{2}$.

Det var nu heller ikke alene de ledende Mænd inden for Ridderskabet, som for Øjeblikket havde opgivet at prøve Kræfter med den danske Enevælde; ogsaa Professor Dahlmann ${ }^{3}$, der som Ridderskabets Sekretær havde formet dets Indlæg, og som klarere og mere maalbevidst end nogen anden havde søgt at samle alle de Kredse, der betød noget, foruden Adelen, Professorerne ved Universitetet i Kiel og Borgerskabet i de større Købstæder, til fælles Stræben i Retning af en friere og mere selvstændig Stilling for Hertugdømmerne, ogsaa han havde tabt Troen paa, at der i Frederik VI.s Rige var nogen Vej frem for de politiske Idealer, som han ønskede at vie sine Kræfter, og forlod skuffet over Holstenernes Træghed og „forbandede Smigreri“ ${ }^{4}$ Landet i I 829, da der aabnede sig en Stilling for ham ved Universitetet i Gøttingen.

Blandt hans Venner og Meningsfæller i Kiel var der ikke saa faa, der ligesom han var fuldt og fast overbeviste om, at Slesvig-Holsten baade retsligt og moralsk havde Krav paa en falles Landdag, og paa at blive styret som et selvstændigt Led inden for Monarkiet uden Ret til Indblanding fra kongerigsk Side; men der var ingen, som baade følte Trang til og evnede at stille sig i Spidsen for en politisk Bevægelse. De slesvigholstenske Retsteorier kunde Professor N. Falck, Bondesønnen fra Emmerlev, udforme i lærde Afhandlinger og mere populære Tidsskriftsartikler; paa det videnskabelige Omraade veg han ikke en Tomme fra, hvad han ansaa for Ret; men naar han stod over for Kongemagten, bøjede han af. Dens Bud var ham den længste Del af hans Liv højeste Ret, uanset hvilke videnskabelige Resultater han gennem sin Forskning var naaet til ${ }^{5}$.

1 Sammlung der wichtigsten Actenstücke die gemeinsamen Angelegenheiten des Corps der Schlesw.-Holst. Prälaten und Ritterschaft und der übrigen Gutsbesitzer betreffend. Neue Folge, von November 1830 bis Julius I 83 I. Kiel [1831], S. 2-3. ${ }^{2}$ Frederik VI i Brev til Höpp ${ }^{27} / 11$ 1830, Zeitschrift, Bd. 24. (1894), S. 200; til Rantzau-Breitenburg, 1/12 30; jvf. Sønderj. Aarb. 19or, S. 200. - Hans Jensen: Anf. Værk, S. 115. ' De nyeste Arbejder om F. G. Dahlmann er O. Scheel : Der junge Dahlmann, Veröffentlichungen der Schlesw.-Holst. Universitätsgesellschaft, IV, Jahrbuch 1925 (ogsaa Schriften der Baltischen Kommission zu Kiel, II, 1926); og O. Brandt: Zur Vorgeschichte der schlesw.-holsteinischen Erhebung, i Archiv für Politik und Geschichte 1926, Heft I0-I I, S. 470 ff. (Ogsaa: Einzelschriften zur Politik und Geschichte, 16. Schrift, Berlin 1927.) - Jvf. Carl Petersens Arbejde om N. Falck (se Note ${ }^{5}$ ), Exkurs, S. I03-I I 1. - Dahlmann har brugt Udtrykket i et Brev af 15/9 183o. Se A. Springer: Fr. Chr. Dahlmann, I. Leipzig 1870, S. 286. S Om Falck, se Werner Carstens: Nicolaus Falck, Schlesw.-Holst. Jahrbuch (Kunst-Kalender), Hamburg 1924, S. 71-73. - Carl Petersen: Nicolaus Falck und die Entstehung des schleswigholsteinischen Gedankens. Veröffentlichungen der Schlesw.-holst. Universitätsgesellschaft Nr. Io. Breslau 1926. S. I-102. 
Heller ikke Dahlmanns Svoger, Lægen Franz Hegewisch ${ }^{1}$, der i Aarene efter I 830 er U. J. Lornsens nærmeste Ven og Støtte, var en Mand, som Fr. VI behøvede at frygte. Vist var han et uroligt Hoved, der hele sit Liv sværmede for en Forfatning efter engelsk Mønster, og Gang paa Gang af Hjertens Lyst rettede en meget nærgaaende Kritik baade mod Bystyret i Kiel og ikke mindre mod Regeringskollegierne, som han nærmest vilde paastaa førte Kongen bag Lyset. Men saa lidt som Falck lod han nogensinde Handling følge paa Ordene, undgik tværtimod omhyggeligt al virkelig Deltagelse i det politiske Liv, f. Eks. da Byen Kiel havde valgt ham som sin Repræsentant til den første holstenske Stænderforsamling ${ }^{2}$, og var med al sin sværmeriske Frihedsbegejstring en yderst kongetro Mand, der, naar alle andre Veje syntes ham spærrede, ikke tog i Betænkning ved en personlig Henvendelse til Landsfaderen at søge at faa sine Planer ført igennem. Det var da kun rimeligt, at Frederik VI paa sin Side gerne var villig til at bære over med "den gode Hegewisch's Exaltationer ${ }^{3}$.

Naar Præsidenten for det slesvig-holstenske Kancelli Otto Moltke saa sent som 28. Sept. 1830 turde forsikre Kongen, at „enhver betydelig Folkebevægelse i Hertugdømmerne" maatte regnes for "det urimeligste af alt, hvad der kan indtræffe" 4, saa stilles hans Ord ganske vist i en højst ejendommelig Belysning ved Lornsens Optræden knap en Maaned senere; men hele Bevægelsens Forløb viser dog, som vi senere skal se, at han i Hovedsagen havde bedømt Forholdene og Personerne i Hertugdømmerne rigtigt.

Og følte man sig paa ledende Sted tryg mod, at der skulde være noget ondt i Gære i Hertugdømmerne, hvorfra dog al Uroen i Aarene efter I 814 var kommet, saa nærede nok selv den noget mistænksomme Frederik VI ingen Bekymringer for Stemningen i Kongeriget. Thi i Danmark, havde en engelsk Diplomat (?) skrevet et Par Aar før, gik det ned ad Bakke med alt, undtagen med Kunst, Litteratur og - Nationens Hengivenhed for sin Konge ${ }^{5}$. I København greb man den første Lejlighed, der frembød sig, til at bevidne sin oprigtige Hengivenhed for Landsfaderen, og den nysgerrige Interesse, hvormed man i mindre Kredse fulgte de store Begivenheder, der gik for sig i Europa, gav sig meget spagfærdige Udslag ${ }^{6}$.

Udenrigspolitisk set var Himlen ganske vist knap saa skyfri. Den franske Julirevolution affødte det belgiske Oprør i August, og i September Maaned kom det

1 Se S. 49, Note ${ }^{3}$. ${ }^{2}$ Wilh. Klüwer: Anf. Værk, S. 417 ff. ${ }^{3}$ I Brev fra Frederik VI til Höpp, 28/10 1830. Zeitschrift, Bd. 24. (1894), S. 196. "Hans Jensen: Anf. Værk, S. $88 .{ }^{5} \mathrm{~J}$. Møller: Mnemosyne, I, I83o, S. 83 (efter Constable's Miscellany 22. vol.; den anonyme Forfatter formodedes at have været $\mathrm{i}$ diplomatisk Tjeneste her $\mathrm{i}$ Landet). Hans Jensen: Anf. Værk, S. 8 o f. 
til Uroligheder i Sachsen, Brunsvig og Kurhessen. Alle tre Steder lød der Krav om Forfatningsreformer, og af Frygt for, at Urolighederne skulde gribe om sig, begyndte Regeringerne i de andre tyske Stater og deres Gesandter paa Forbundsdagen at røre paa sig. De af de tyske Stater, der vidste med sig selv, at de havde sikret sig paa bedst mulig Maade mod en saadan Ildebrand ved at opfylde Forbundspagtens $\S$ I 3 og anskaffe sig en lille nem Lynafleder, nemlig en fri Forfatning, oftest blot i Form af raadgivende Provinsialstænder, saa med stigende Bekymring, hvad det kunde føre til, at flere Medlemmer af deres gensidige Forsikringsselskab havde forsømt at faa denne lille Sikkerhedsforanstaltning i Orden.

Skønt man ikke gerne greb ind i de andre Staters indre Anliggender, drev Frygten for nye Oprør dog Forbundsdagen til at lade de forsømmelige Stater forstaa, at man nu ikke burde opsætte længere at indføre noget i Retning af en raadgivende Stænderforfatning. Ogsaa Danmark modtog underhaanden en saadan Henvendelse fra ingen ringere end den østrigske Gesandt ved Forbundsdagen. Den naaede til København d. 24. Sept ${ }^{1}$. Dog synes det at være lykkedes vore Gesandter at faa saa vel den østrigske som den preussiske Regering til at forstaa og godkende den danske Regerings Synspunkt, at den daværende urolige Tid ikke egnede sig til at sætte Forfatningsforhandlinger i Gang, da det let vilde kunne udtydes, som om Regeringen var bange, og føre til, at man fra urolige Elementers Side mødte med vidtgaaende Krav. Vi undgik da lykkeligt, at man fra Forbundsdagens eller de to tyske Stormagters Side stillede bestemte Krav til os eller satte nogen bestemt Frist for Opfyldelsen af Forbundspagtens $\S$ I 3 ; den danske Regering mente atter selv at kunne være Herre over, hvornaar og hvordan Sagen skulde gribes $a^{2}{ }^{2}$. At der imidlertid nu inden for en overskuelig Tid maatte findes en Løsning paa Spørgsmaalet, turde det dog ogsaa nok være berettiget at slutte.

Allerede inden den udenrigspolitiske Himmel var blevet nogenlunde klar igen, trak der Skyer op over den holstenske, og slemme Rygter naaede Kongens Øre. Hemmeligt Politi kendte vi ikke til i Frederik VI.s Monarki; men det var ogsaa saa inderlig overfødigt. De Indberetninger, som i andre Lande det hemmelige Politi besørgede, var herhjemme overladt til det private Initiativ, og det svigtede heller ikke den Tillid, Majestæten viste det. Der var baade smaa Nattergale, og især mange større Fugle med mere spraglet Fjerdragt, men knap saa melodiske Stemmer, der kappedes om at synge Bynyt i Oret paa den gode,

${ }^{1}$ Anf. Værk, S. 8I f. ${ }^{2}$ Om den diplomatiske Forhandling, se anf. Værk, S. 8o-88. Jvf. K. Fabricius anf. Artikler i Berl. Tid. $1 / 111930$ og $29 / 51931$. 
gamle Konge, som helst vilde „høre alle" 1 . Alle Embedsmænd maatte endvidere ved deres Tiltrædelse af Embedet aflægge Ed paa, at de vilde indberette ethvert Attentat mod Enevælden, og at det blev taget alvorligt, viser Harms's Anmeldelse af Rygterne om Lornsenrøret ${ }^{2}$. Som oftest var Frederik VI da underrettet om Døgnets store og smaa Begivenheder tidligere og udførligere end hans Ministre, og det slog ogsaa til i dette Tilfælde. Gennem Breve til og fra Frederik VI og et Par af hans betroede Mænd, Gesandten i St. Petersborg Otto Blome og Kancellideputeret J. P. Höpp, Okt. I83o, faar vi at vide, at der i Kiel har været Stemning for at samle Underskrifter paa en Petition til Kongen om en fælles Forfatning for begge Hertugdømmerne, men at Oprørene $i$ Tyskland havde virket saa skræmmende, at man havde ladet Planen falde ${ }^{3}$. De sidste Meldinger til Kongen lød paa det Punkt absolut beroligende.

Men Frederik VI, der af Natur og gennem Erfaring var noget mere mistroisk end adskillige af dem, der omgav ham, øjnede allerede da Faren ved, at Meddelelser fra Forbundsdagen i Frankfurt muligvis kunde naa ned til de Kredse i Holsten, der ønskede en Forfatning, og give dem Mod til paa ny at rejse Kravet ${ }^{4}$. Paa en Maade var det virkelig det, der skete; thi naar Hans Jensen i Værket om de danske Stænderforsamlinger bemærker, ,, at saafremt dette Motiv [Rygterne om, at Forbundsdagen havde stillet Krav til den danske Regering om nu at gøre Alvor af at give Holsten en Stænderforfatning] havde været meget fremtrædende, vilde vi sikkert ikke nu have behøvet at søge til Arkivgemmerne for at finde, at det holstenske Spørgsmaal ogsaa i Efteraaret I83o havde en udenrigspolitisk Side $^{c 5}$, saa kan dertil siges, at det kunde man være naaet til Klarhed over alene ved en Gennemgang af det trykte Materiale fra den Tid.

En af U. J. Lornsens nærmeste Venner fra Studenteraarene, baade i Kiel og Jena, og tillige en af de ivrigste $i$ hele Petitionsbevægelsen i i 83o, var en Dr. A. Binzer. Han var en frisk og aaben Fyr med et Overskud af Kræfter og lidt Hang til at vise sig og drive alt paa Spidsen efter Turnvater Jahns Forbillede. Schumacher giver et Par baade morsomt sete og i det store og hele ganske tiltalende Situationsbilleder af ham i sin Bog ${ }^{6}$. Iøvrigt var han en af de yderst faa,

1 Hans Jensen: Anf. Værk, S. I 19. ${ }^{2}$ Cl. Harms: Lebensbeschreibung verfasst von ihm selber. Kiel 1851, S. 138. Jvf. K. Jansen: U. J. Lornsen. Kiel 1872, S. 234 f. ${ }^{3}$ Hans Jensen: Anf. Værk, S. go. - Sønderjydske Aarbøger I gor, S. I 72 f. og I 75, jvf. S. 220. - Neues staatsbürg. Magazin, I, Schleswig I833, S. 360 f. ${ }^{4}$ Hans Jensen: Anf. Værk, S. 86. - Zeitschrift, Bd. 24. (1894), S. 196. ${ }^{5}$ Hans Jensen: Anf. Værk, S. $95 . \quad{ }^{6}$ Om A. Binzer, se G. F. Schumacher: Genrebilder aus dem Leben eines siebenzigjährigen Schulmannes. Schleswig I841. S. 474-477. - Sønderj. Aarb. 1901, S. 203. - K. Jansen: Anf. Værk, S. 268 Noten. 
der turde staa ved, hvad han havde gjort og sagt, og kæmpe med aaben Pande lige saa fuldt som Lornsen selv. Kort efter at Lornsen er blevet fængslet, da de fleste kryber i Skjul, udsender han en Pjece til Forsvar baade for Lornsen og hele Bevægelsen, og vel at mærke - under Navn ${ }^{1}$. Heri nævner han blandt andet, at Ønsket om en Forfatning havde været levende, allerede før det forlød, at man i København ikke ugerne vilde se Petitioner om passende Reformer netop paa dette Tidspunkt ${ }^{2}$.

Og hvad dette Rygte, som Binzer her omtaler, i Enkeltheder er gaaet ud paa, det faar vi Besked om i Wit v. Dörrings allerede nævnte Pjece: „Was uns Noth thut ". „For at rydde enhver Anledning til Uroligheder i de tyske Stater af Vejen, skal Forbundsdagen have fastsat en uigenkaldelig sidste Frist, inden for hvilken Hans Majestæt Kongen af Danmark, som Hertug af Holsten, skal have bragt Forbundspagtens $\S$ I 3 til Udførelse “ 3 . Hermed har man (stadig i Følge Wit v. D.) sat mange, maaske rent tilfældige Hændelser i Forbindelse, saaledes navnlig Etatsraad Höpps Ankomst til Kiel (samtidig med Lornsen), idet man troede, at hans officielle Hverv, at undersøge Nøden i Marskegnene, nærmest var et Paaskud for at skjule hans egentlige Erinde (hvad det jo ogsaa virkelig var). „Snart hed det sig, og det vilde maaske være svært at bestemme, om denne Opfattelse var blevet lavet og udbredt kunstigt, eller om de, der havde udformet den, havde handlet $\mathrm{i}$ god Tro, at Kongen havde sendt dette udmærkede Medlem af det højeste Kollegium til Hertugdømmerne for virkelig at lære Stemningen i Landet og Undersaatternes Ønsker og Begæringer at kende, og at Kongen skulde være beredt til at give Landet en Forfatning, hvis den offentlige Mening ellers udtalte sig afgjort $\mathrm{i}$ den Retning, og at han derfor ønskede, at man udtalte sig frit herom "4. Ogsaa Lornsens Optræden blev naturligvis sat i Forbindelse med disse Rygter, og hans Udtalelser betragtet som halvvejs officielle.

Og dersom man endnu ikke efter ovenstaaende føler sig overbevist om, at Rygtet om et Tryk fra Forbundsdagens Side har spillet en vis Rolle for Lornsenrøret i Kiel, saa findes der endnu en Beretning om det samme, hvis Ophavsmand nyder den mest ubetingede Tiltro for sin Sanddruhed; den stammer fra N. Falck og foreligger trykt $i$ hans „Neues staatsbürg. Magazin" under nogle Notitser om Begivenhederne i Aaret $1830^{5}$. Med Udgangspunkt i den officielle Meddelelse om Lornsens Fængsling og Dom giver han en kort Oversigt over Petitionsbevægelsen og dens Forhistorie. Efter stærkt at have betonet, at For-

1 Dr. A. Binzer: Ein Wort zur Verteidigung in Betreff der schlesw.-holst. Petitions-Angelegenheit, Kiel 183o. Jvf. K. Jansen: Anf. Sted, S. $268 \mathrm{ff}$. 2 Binzer, Anf. Sted, S. 17. 3 Anf. Sted, S. 8. Anf. Sted, S. 9. 5 Anf. Værk, Schleswig I833, S. $360-36 r$. 
fatningsønskerne ikke just var skrinlagt i Hertugdømmerne, fordi den offentlige Drøftelse af dem var forstummet, og vedgaaet, at Julirevolutionen baade forstærkede Interessen hos tidligere Forfatningsvenner og skaffede Ønskerne Indpas i videre Kredse af Befolkningen end før, oplyser han, at der allerede paa dette Tidspunkt var Tanker fremme om at indgive en Petition, og at de fandt Sangbund hos mange. Og saa fortsætter han: „Dertil kom endnu den Efterretning, som virkelig ogsaa blev bekræftet i de offentlige Blade i Slutningen af November Maaned, at den tyske Forbundsdag havde tilstillet samtlige Regeringer en Opfordring til at opfylde de Forpligtelser mod deres Undersaatter, som paahvilede dem efter Forbundets Love. En saadan Beslutning var virkelig blevet fattet d. 2 I. Okt. $1830^{1}$. Nu troede flere - og de kunde maaske ved Rygter, der saa let opstaar i mere bevægede Tider, uden at man rigtig ved hvordan, have fundet Bekræftelse herpaa, - at det vilde være selve Regeringen kærere, hvis Forfatningssagen paa ny blev bragt paa Bane gennem Undersaatternes Bønner, frem for hvis det skete gennem en Opfordring fra Forbundsdagen. Saaledes kom Spørgsmaalet frem om Affattelsen af et Bønskrift til Hans Majestæt Kongen, og Kancelliraad Lornsen var ganske vist den, som under sit Ophold i Kiel i Slutningen af Oktober og Begyndelsen af November især interesserede sig for Sagen."

Endelig har ogsaa Graae efter Procesakterne kunnet paavise, at Lornsen har hørt Rygtet senest om Bord paa Damperen fra København til Kiel ${ }^{2}$. Efter dette turde det ligge klart for Dagen, at Rygterne fra Frankfurt virkelig har spillet en ikke uvæsentlig Rolle i Kielerrøret, hvad enten Lornsen er den, der har udbredt dem dernede eller ej.

Et andet Spørgsmaal er der samtidig blevet kastet Lys over, det nemlig, hvorvidt der allerede havde været en Petitionsbevægelse i Gang, før Lornsen greb ind, saaledes som det saa tidligt som d. 9. Okt. blev indberettet til Frederik VI ${ }^{3}$. Baade Binzer ${ }^{4}$ og Wit von Dörring ${ }^{5}$ bekræfter jo, at der var ved at komme Ønsker frem, fra det Øjeblik Julirevolutionen naaede Hertugdømmerne, og Wit vil endda vide, at Ridderskabet vilde have indgivet en Petition, hvis ikke Begivenhederne i Belgien havde virket saa skræmmende ${ }^{6}$. Disse Ønsker nævnes ogsaa hos Falck i den omtalte Artikel ${ }^{7}$ og ligeledes i en Bemærkning i den Redegørelse,

1 Jvf. Th. Graae: U. J. Lornsen. Kbh. 189i. S. 96, Anm. 2. 2 Anf. Sted. - Jvf. ogsaa Kancelliprasidenten O. Moltkes Dementi af Rygtet i Brev til Höpp \% 11 I83o; Zeitschrift, Bd. 24 . (1894), S. 205, og Hans Jensen: Anf. Værk, S. 87. ${ }^{3}$ Hans Jensen: Anf. Værk, S. 9o. ${ }^{4}$ Binzer: Anf. Sted, S. I7. $\$$ Wit: Anf. Sted, S. 9. Anf. Sted, S. 4. - Jvf. Brev fra Gesandten i Rusland Grev O. Blome til Frederik VI, 19/10 1830, Sønderj. Aarb. I9or, S. I 75. ' Neues staatsbürg. Magazin, I (1833), S. 360 f. 
han d. 9. Nov. sender sin Ven i Kancelliet, den Deputerede J. Fr. Jensen ${ }^{1}$, saa vel som i den Erklæring af 25. Nov., som han har afgivet til Höpp: „Som jeg i disse Dage har erfaret, var der allerede før Lornsens Ankomst (19. Oktober) i et Selskab her udkastet en Ide om at petitionere" "2. Grev Carl Schimmelmann vil have lokket ud af den unge Historieprofessor fra Kiel, A. L.J. Michelsen, der er paa et Besøg i København Sept.-Okt. I830, at nogle Advokater i Kiel (Witte og Preusser, som ogsaa tager stærkt Del i Lornsen-Bevægelsen) allerede hemmeligt lod en Petition om en slesvig-holstensk Fællesforfatning cirkulere og haabede at have mange Tusinde Underskrifter endnu inden Kieler Omslag næste Aar ${ }^{3}$. Alt tyder dog paa, at det ikke er kommet saa vidt ${ }^{4}$; hermed stemmer ogsaa den mundtlige Tradition hos Jansen om Ordskiftet i København og paa Skibbroen i Kiel, hvorefter Lornsens første Spørgsmaal til Vennerne er: „Har I petitioneret? ${ }^{*} 5$

Og hermed er vi naaet til den Kraft, der skulde tænde Gnisten paa ny, netop, som det meldtes fra alle Sider, at den var helt slukket. Thi kom Forfatningsrøret i Kiel ikke just som Lyn fra en klar Himmel, saa trak Uvejret dog op fra en Kant, hvorfra man mindst havde ventet det. Den Mand, der skulde faa Forfatningsbevægelsen til at blusse op paa ny og skabe et Røre, som kom til at volde Konge og Regering og mange brave Borgere adskillige urolige Timer, var en af Regeringens egne betroede Mænd, Kancelliraad, hidtilværende Kontorchef, Uwe Jens Lornsen, der ved hver ny Forfremmelse inden for Kancelliet var blevet rost for sin mønsterværdige Flid, utrættelige Iver og store praktiske Dygtighed, hvorved han havde kunnet udføre selv de vanskeligste Arbejder til Kancelliets fulde Tilfredshed ${ }^{6}$, og som var blevet anbefalet af samme Kancelli til den ledige Post som Landfoged paa hans Fødeø Sild med Vidnesbyrd om, at han ejede en sjælden skarp Forstand og usædvanlige aandelige Anlæg og Kundskaber, ja med Garanti for hans Redelighed og moralske Værd?.

Hvor er det muligt, at alle hans Foresatte kan have taget saa grundigt fejl af hans Paalidelighed og Skikkethed til at bestride en ret selvstændig Post som en af Hans Kgl. Majestæts tro Tjenere? Og hvordan kan det gaa til, at en Mand, der i ni Aar tilsyneladende har fundet sig ret vel tilpas „inden for Murene“ som et Led i Enevældens Embedsmaskineri og aabenbart en Tid lang har haft sin Ergerrighed rettet mod at naa op $i$ selve de styrendes Kreds som Kancelli-

1 Zeitschrift, Bd. 58. (1929), S. 586. ${ }^{2}$ Sønderj. Aarb. 19or, S. 220. $\quad{ }^{3}$ Anf. Sted, S. 172 f. 4 Anf. Sted, S. 175 f. ${ }^{5}$ K. Jansen: Anf. Værk, S. $202 .{ }^{6}$ W. Jessen (og G. E. Hoffmann): Uwe Jens Lornsens Briefe an seinen Vater. Breslau 1930, S. $105^{4}$ og S. $124^{1}$. 7 P. Richter: Anf. Værk, S. $5^{85}$. 
deputeret $^{\mathbf{1}}$, nu pludselig bryder ud og uden at tage Hensyn til, hvad der var gældende Opfattelse af Embedspligter, hvad Konge eller Overordnede maatte tænke, hvordan det vilde berøre hans Nærmeste, saa lidt som til, hvilke Følger det vilde faa for hans egen Fremtid, sætter sig i Spidsen for en Forfatningsbevægelse, som han med Sikkerhed maa vide, vil bringe ham i den skarpeste Modsætning til Landets Konge og Regering?

At det har været en højst pinlig Overrumpling for hans Foresatte ${ }^{2}$ (saa vel som for hans Fader ${ }^{3}$ ) lyser ud af deres Breve fra den Tid. Kun en enkelt synes allerede tidligere at have følt sig frastødt af Lornsens selvbevidste Optræden 4 Naar man vil søge at forstaa, hvordan Kancelliembedsmanden U.J. Lornsen ligesom skyder Ham og med eet staar som Fører for det unge Slesvig-Holstens politiske Krav, er det i hvert Fald nødvendigt at fremdrage et Par Træk af hans Udvikling, før han nødtvungent slog sig til Ro blandt de gulnede Akter i Kancelliet.

Den kæmpestore Skikkelse og den vældige Naturkraft i ham havde han i Arv fra frisiske Forfædre paa Sild. Noget uregerlig og vild havde han været som Dreng, hvad Legekammeraterne fik at føle, naar de ikke vilde lystre ham som deres selvskrevne Fører ${ }^{5}$. Krigen med England hindrede ham i at gaa til Søs som hans Fader og øvrige Slægt før ham, og mens Aar efter Aar sled sig hen med Venten paa, at Krigen skulde høre op, fik han nok i højere Grad, end godt var, Lov at være sin egen Herre uden alt for strengt Arbejde. I Efteraaret I8I I, da han næsten var I8 Aar gammel, blev det omsider afgjort, at han skulde gaa den læsende Vej. De første to Aar tilbragte han i Tønder som "Seminaristelev " ${ }^{6}$ ved Byens Borgerskole, de næste Par Aar (med ret store Afbrydelser) i Slesvig, og uden egentlig Studentereksamen ${ }^{7}$ blev han i Foraaret $1816221 / 2$ Aar gammel indskrevet som Student ved Universitetet i Kiel. Baade som Skoleelev og Student maa han, alene i Kraft af sin Alder, men jo ikke mindre ved sin naturlige Begavelse, i mange Maader have været de fleste af sine Kammerater betydeligt overlegen. Dermed hænger vel noget sammen, der allerede saa smaat spores i Brevene fra Skoleaarene: de lidt flotte Vaner, han begyndte at lægge sig til ${ }^{8}$, og som faar

1 Anf. Sted, S. 58r. 2 Zeitschrift, Bd. 24. (r894), S. 209 og 212 f. - Sønderj. Aarb., I9or, S. I89. - Hans Jensen: Anf. Værk, S. 97. ${ }^{3}$ Jansen: Anf. Værk, S. 287. - Jvf. „Der Schleswig-Holsteiner" r930, S. 372. Zeitschrift, Bd. 24. (I894), S. $213 .{ }^{5}$ Notizen, S. 9 f. 6 Jessen: Briefe, S. I, Anm. 6. 'Anf. Værk, S. 24, Anm. ${ }^{8}$ Han lejer Ridehest; anf. Værk, S. 8. Jvf. Notizen, S. 13. - W. Jessen vil derimod ikke indrømme, at det har sin Rigtighed med Flotheden. Se „Der Schleswig-Holsteiner“, I930, S. 4 16. 
Regningerne, som Faderen skal bestride, til bestandig at overskride de fastsatte Beløb ${ }^{1}$. Sin Selvstændighedstrang lægger han for Dagen ved at ræsonnere over, hvilke Fag det vil være nyttigst for ham at give sig af med (Tønder) ${ }^{2}$; eller over, hvor det vil gaa bedst med hans Studier, i Slesvig eller hjemme paa Sild ${ }^{3}$. Ogsaa smaa psykologiske Studier ${ }^{4}$ forekommer (Værtsfolkene i Tønder ${ }^{5}$, Rektoren sammesteds $\left.{ }^{6}\right)$. Endelig træder endnu et Træk tydeligt frem: hans hyppige Betragtninger over sin egen Sundhedstilstand og Beskrivelse af de Sygdomsanfald, som med Aarene blev flere og kraftigere og endte med at nedbryde Legeme og Sjæl.

I det hele taget maa det siges, at han har været en flittig Brevskriver og holdt sin Fader underrettet om sine øjeblikkelige Forhold, ligesom han altid, hvor større Afgørelser skal træffes, ærbødigt udbeder sig Faderens Tilladelse, og ogsaa langt op i Aarene bøjer sig for Faderens Afgørelse, selv naar den gaar stik imod hans Planer, hvad der dog muligvis kan bunde noget i hans økonomiske Afhænggighed af Faderen. Men selv en saa aaben og ærlig Natur som U. J. Lornsen, der omfatter sin Fader baade med Hengivenhed og Ærbødighed, betror nu engang ikke til sit Hjem alt, hvad der rører sig i ham, eller alt, hvad han tager sig for. Det er vi i Stand til at kontrollere baade for Kiel- og Jenatidens Vedkommende. Hverken om Duellen i Kiel ${ }^{8}$ eller om sin personlige Deltagelse i Ledelsen af Burschenschaftbevægelsen i Kiel og Jena ${ }^{9}$ meddeler han Faderen det mindste. Derfor behøver man næppe at tage den „Normalarbejdsdag“ fra Opholdet i Kiel, som han til Beroligelse for Faderen skildrer saa indgaaende ${ }^{10}$, alt for højtideligt. Hvis Studenterlivet i Kiel havde formet sig saa regelmæssigt, havde han næppe to Aar senere behøvet at udrede for sig selv og Faderen, hvorfor Juraen ikke var blevet dyrket tilbørligt ${ }^{11}$. Hermed skal ingenlunde være sagt, at han bevidst har fortiet noget, som han mente at skylde Faderen Regnskab for, saa lidt som, at han har sløset al sin Tid bort i Svir og Letsindighed. Kunde det siges om Studenterlivet i Kiel, som Lornsen selv, bortset fra den nævnte „Normalarbejdsdag", kun giver yderst sparsomme Oplysninger om, mens Burschenschaftsprotokollerne fra den Tid lader os skimte adskilligt mere, at Fornøjelser og Selskabelighed virkede stærkt spredende paa Studenternes Arbejde, og at Studiet nærmest var en Biting ${ }^{12}$, saa stemmer alle Beretninger fra den

1 Anf. Værk, S. I3 f., S. I9 f. og talrige Gange siden. ${ }^{2}$ Anf. Værk, S. I I f. ${ }^{3}$ Anf. Værk, S. 23 f. 4 Anf. Værk, S. 15. 'Anf. Værk, S. 12 f. 'Anf. Værk, S. 15. ' Anf. Værk, S. 8, 10, 22. ${ }^{8}$ Anf. Værk, S. 32 Noten. "Der Schleswig-Holsteiner" 1930, S. 526-531. ${ }^{10}$ Jessen: Briefe, S. 28 f. 11 Anf. Værk, S. 56. ${ }^{12}$ Georg Beseler: Erlebtes und Erstrebtes. 1809-1859. Berlin I884. S. 8 . 
Tid $^{1}$ overens med Lornsens Fremstilling, naar han paa Bekostning af de ældre Studentertraditioner og sin egen Livsopfattelse og Levevis i Kielertiden priser den Aand, der raader blandt Studenterne i Jena ${ }^{2}$. Han føler det, som denne Aand er blevet lutret ved de „høje og ædle Maal“, som Professorer og Studenter i Samdrægtighed arbejder henimod, at gøre de „saa længe despotisk undertrykte Menneskerettigheder og Fædrelandsfølelsen " 3 gældende og opretholde dem.

Det, der gjorde Studenterlivet, og ikke mindst i Jena, saa værdifuldt i disse Aar, var først og fremmest det, at de yngre Professorer og de ældre Studenter gennem fælles Deltagelse i Frihedskrigen mod Napoleon var kommet i et halvt kammeratligt Forhold til hinanden, og følte sig knyttede sammen ikke blot af de fælles Oplevelser, men ogsaa i fælles Haab og Stræben for Tysklands Fremtid 4. Dette lod dem se deres Liv og Virke i et Skær, som ikke kunde forenes med det gamle Studenterlivs Raahed og Udskejelser. Paa den anden Side steg Selvfølelsen hos disse Krigsdeltagere til en undertiden uhyggelig Højde ${ }^{5}$. Ligesom man ved egen Kraft havde brudt Trældommens Lænker udadtil, vilde man nu bryde dem indadtil og tilkæmpe sig indrepolitisk Frihed. Lige saa brændende utaalmodigt man havde kæmpet for at tage Hævn over fransk Undertrykkelse, lige saa haardt og hensynsløst vilde man nu føre Kampen mod Frihedens Fjender i selve Tyskland, Fyrsterne og deres hele Slæng af lejede Tjenere.

At der i den brogede Studenterflok brødes højst forskellige Meninger og fandtes et Utal af Afskygninger, naar det gjaldt Vurderingen af politiske Maal og Midler, siger sig selv. Paa Torvet i Jena vilde man have kunnet træffe baade den stokkonservative, adelige Korpsstudent og den radikaleste af de radikale, Dr. Karl Follen ${ }^{6}$, for hvem Burschenschaft-Bevægelsen kun var romantisk Barneleg.

${ }^{1}$ Schumacher: Genrebilder, S. $472 \mathrm{ff}$ - Wit v. Dörring: Fragmente aus meinem Leben und meiner Zeit. Leipzig I833, S. 5 ff. - H. Leo: Aus meiner Jugendzeit. Gotha 188o, S. 143 ff. H.v. Treitschke: Deutsche Geschichte im Neunzehnten Jahrhundert. II. 8. Oplag. Leipzig 191 7, S. 416. - P. Wentzcke: Geschichte der deutschen Burschenschaft, I, Quellen und Darstellungen zur Geschichte der Burschenschaft ... Bd. VI, Heidelberg I919, S. I 52 ff. Se især S. I6 I f. ${ }^{2}$ Jessen: Briefe, S. $3^{8}$ f. og $4^{8} \mathrm{ff} .{ }^{3}$ Anf. Værk, S. ${ }^{8}$. 'Anf. Værk, S. 39. - Wit v. Dörring: Fragmente I, S. 5 f. - Wentzcke: Anf. Værk, S. I 3 ff. ${ }^{5}$ Wit v. Dörring: Anf. Værk, S. 7 f. Wit v. Dörring: Fragmente, I, S. 22 ff. Samme Forfatter: Mein Jugendleben und meine Reisen. Leipzig I833, S. 49 ff. - H. Leo: Anf. Værk, S. I 76 ff. - Treitschke: Anf. Værk, S. 437 ff. Jvf. Graae: Anf. Værk, S. 63 ff. - Wentzcke: Anf. Værk (se Registret), især S. r 34 f., $304 \mathrm{ff}$., 3 I I ff. - H. Haupt: Karl Follen i „Hundert Jahre Deutscher Burschenschaft. Quellen und Darstellungen zur Geschichte der Burschenschaft . . . Bd. VII, Heidelberg 192 I, S. $25-38$. — Wilh. Jessen, „Neues über den jungen Lornsen“, „Der Schleswig-Holsteiner“ 1930, S. 419422. (I de tre sidstnævnte Værker ogsaa fyldige Litteraturhenvisninger.) 
U. J. Lornsen var nu allerede i Kiel begyndt at fatte Interesse for de nye Tanker, der hurtigt vandt Indpas i Studenterverdenen, idet vi kan se, at han havde meldt sig som Deltager i Wartburgfesten, uden dog at gennemføre Planen (det var vel Pengene det kneb med? ${ }^{1}$ ). Men April I8I8 kommer han til Jena som en af Kieler Studenternes officielle Repræsentanter for at tage Del i Grundlæggelsen af det almindelige tyske Burschenschaft. Her i den fuldkommen frie og ubundne, gærende Studenterverden med dens højtspændte Forventninger og begejstrede Drøftelser af, hvordan de store, straalende Maal hurtigst lader sig gennemføre, føler Lornsen sig som genfødt; her faar han sit aandelige Hjem. I hans Breve til Faderen viger den nøgterne, berettende Tone for begejstrede Udbrud af de Tanker og Følelser, der nu giver Livet nyt Værd for ham ${ }^{2}$.

I den Beretning angaaende Stiftelsen af det første almindelige Burschenschaft, som han og Rejsefællen M. W. Reiche sender hjem til Kammeraterne i Kiel ${ }^{3}$, hedder det, „at intet vil binde os tyske Burscher saa meget sammen, som Overbevisningen om, at alle vi, der taler Tysk, er Sønner af Eet Fædreland, og derfor nu og i Fremtiden kan bidrage uendelig meget til i vor Virkekreds at fremme Kærligheden til vort Folk og Vækkelse af folkelig Sæd og Skik “. Det er den berusende Følelse af det tyske Folks Enhed trods al sin øjeblikkelige Splittethed, der slaar Rod i Provinsstudenten, som i sin Hjemstavn kun har haft det nære og daglige for $\emptyset_{\mathrm{j} e \text {. }}$

Men mindst lige saa dybt og lige saa varigt gennemtrænges han af et andet Sæt af Tanker, som allerede kom til Orde i det tidligere nævnte Brev til Faderen. Det er Ønsket om og Arbejdet paa ved Siden af Fædrelandskærligheden at vække Sansen for de „saa længe despotisk undertrykte Menneskerettigheder"4, at fylde alles Hjærter og Hjærner med Kærlighed til Retfærdighed, Fædreland og Frihed ${ }^{5}$. Det er det offentlige Liv, der lokker ham, vel at mærke ikke i uindskrænkede Monarkier, hvor Undersaatterne i politisk Henseende er at regne for kastrerede Væsener ${ }^{6}$, allermindst „det snævrere Fædreland, Slesvig-Holsten “, hvor al Sans for offentligt Liv enten er uddød eller aldrig har eksisteret, hvor man, naar Dagens Pligtarbejde er til Ende, ikke ved noget bedre end at gaa i Selskab og der for ikke at kede sig sætter sig til at spille Kort eller drikke - med det Resultat, at alle (Akademikere) paa faa Undtagelser nær synker uhjælpeligt ned i Dagliglivets Dynd og mister Sansen for alt skønnere og højere her i Livet?

1 „Der Schleswig- Holsteiner“ 1930, S. 526. Jvf. S. 417. 2 Betydningsfulde er især de to Breve Nr. 50 og 52, skrevet henholdsvis 27. April og en af de første Dage i August 18 r8. Jessen: Briefe, S. 37-45 og 47-55. " „Der Schleswig-Holsteiner" 1930, S. 527 f. " Jessen, Briefe, S. $4^{8 .}{ }^{5}$ Anf. Værk, S. 49.

- Anf. Værk, S. 5o. 7 Anf. Sted. 
Lornsen har næppe været en Maaned i Jena, før han i et Brev til Faderen bekender, at han har tabt Lysten til at studere $\mathrm{Jura}^{1}$ (om den nogensinde havde været synderlig stor, tør vist betvivles). Det, der drager og lokker ham til sig, jo mere han lærer, erfarer og overvejer, og ansporer ham til at udvide sine Kundskaber, saa meget der er ham muligt og Juraen tillader det, er: det offentlige Liv, og Ønsket om paa dette Felt at kunne sætte sine Kræfter ind med Udsigt til et godt Resultat ${ }^{2}$. Men da han ikke synes, der frembyder sig nogen Mulighed for et daadkraftigt Liv i den slesvig-holstenske Smaaborgerlighed derhjemme, spejder han videre ud. Og i det nævnte Brev af 27. April 1818 forelægger han sin Fader en Plan, der nok tør siges at gaa noget ud over det almindelige ${ }^{3}$ : Befolkningen paa Haiti har for nogle Aar siden revet sig løs og gjort sig selvstændig. Dens Konge Henry er efter alt, hvad man ved, en overmaade viis og god Konge, men Folket er naturligvis ukultiveret, og der vil kunne gaa over 20 Aar, før der er nok af kundskabsrige og dannede Mænd, der kan hjælpe ham med at organisere hans Rige, og for saadanne Mænd maa der da paa Haiti frembyde sig enestaaende Chancer.

Hver Mand, der ikke hører til Nitterne, men overhovedet fortjener en Plads her i Verden, har nu efter Lornsens Mening Pligt til at prøve sig selv alvorligt og strengt, indtil han med Bestemthed kan sige: Paa denne Plads vilde jeg kunne gavne Verden mest og gøre mig saare nyttig; og naar først han er naaet til Erkendelse heraf, er det lige saa fuldt hans Pligt at stræbe efter at opnaa denne Plads. Dette mener Lornsen nu at gøre ved at udbede sig Faderens Billigelse af, at han søger sin Lykke paa Haiti, saa snart han er vel forberedt dertil. Slægtens Søfarerblod kræver sin Ret. Han er 25 Aar og har ikke som Faderen og de andre faaet Lov at prøve - og tæmme - sine Kræfter i Kamp mod en jævnbyrdig Fjende.

Da Faderen mærkværdigvis ikke i mindste Maade gaar ind paa hans Ideer, men anfører en Række afskrækkende Modgrunde, opgiver Lornsen ikke just Planen, men lader den bero indtil videre, og bedyrer, at han vil sætte alt ind paa at uddanne sig saa alsidigt og grundigt som muligt ${ }^{4}$.

Ogsaa mod de nordamerikanske Fristater retter han sit Blik; thi her alene paa den ganske Jord er der sand Frihed og Menneskelighed, her, hvor ingen Fyrste og ingen Adel saa lidt som andre Privilegier gælder noget, her bedømmes en Mand efter Værd og Fortjeneste. Dog endnu skønnere end at føre saa frit og herligt et Liv her [i Amerika], er det at være behjælpelig med at hidføre en saa-

$127 / 4$ 1818. Anf. Værk, S. 39 f. 2 Anf. Værk, S. 50. ${ }^{3}$ Anf. Værk, S. 41. Anf. Værk, S. $5 \mathrm{I}$. 
dan Tilstand i andre Lande og især i Fædrelandet. Men, sukker han, man maa jo tabe Mod og Lyst, naar man har den sikre Udsigt for $\emptyset_{\mathrm{je}}$, at selv et Liv fuldt af Virken og Taalen ikke vil føre os synligt nærmere til dette Maal ${ }^{1}$.

Hvor faar Lornsen disse nye Tanker fra? Vist stemmer de godt med hans kraftige, selvstændige Natur, men alligevel maa de jo være strømmet ind over ham i utrolig kort Tid, som en Flod, der efter Snesmeltningen gaar over sine Bredder, skummer og bruser, men efterlader et Lag frugtbar Jord, hvoraf ny Sæd kan spire frem.

Straks ved sin Ankomst er han midt inde i Burschenschaftbevægelsen, hvis Idealer han giver Udtryk for paa et Par Stambogsblade. Det ene ${ }^{2}$ slutter (i Oversættelse): (lige meget fra hvilken Egn i Tyskland vi end er) „Dog omslynges vi alle af Eet Broderland, Alle er vi Stridsmænd for Eet og det samme Fædreland“. Og nedenunder de tre Ord: „Gud, Frihed, Fædreland!", som samme Dag højtideligt var blevet fastslaaet som det almindelige Burschenschafts Valgsprog, medens et halvt Aar senere „Gud“ gled ud og erstattedes af „Ære“ ${ }^{3}$.

Det andet ${ }^{4}$, skrevet til en Student ved Navn Haupt over det kendte Bibelord, er maaske endnu mere betegnende for den Aand, der raadede, og ikke mindst for, hvad den officielt fastslaaede Tilknytning til den kristne Tro betød. Det lyder paa Dansk: „Lucifer Haupt! gaa ud i Verden: belær og omvend Hedningerne; døb dem i det tyske Fædrelands Fres, Friheds og Enheds Navn!"

Ogsaa fra Universitetslærerne udgik der imidlertid Impulser, som virkede fængende og ansporende paa Studenterne. Som allerede nævnt stod flere af Professorerne paa en ret fortrolig Fod med Studenterne, og gennem Forelæsninger med et vist aktuelt Tilsnit, som Fries's ${ }^{5}$ over historisk-filosofiske Emner eller Ludens ${ }^{6}$ over historisk-politiske, kunde de paavirke et stort Antal af Studenterne; endnu flere fik de maaske i Tale gennem deres "populærvidenskabelige" Afhandlinger. I det lille thüringske Hertugdømme, der var det sikreste Fristed i Tyskland for frisindede Anskuelser, udkom der i Byerne Weimar og Jena ikke mindre end 7, efter den Tids Aand folkeligt skrevne, Tidsskrifter?,

1 Anf. Værk, S. 50. ${ }^{2}$ Skrevet 2. April 1818. Anf. Værk, S. 36 og Anm. 3. ${ }^{3}$ Wentzcke, Anf. Værk, S. 264 og 286. Om den sidstnævnte Affattelse synes der dog ikke at være fattet nogen formelig Beslutning. 4 Den samme Haupt, som senere sagde god for Lornsen ved Undersøgelsen. Skrevet den 30. Marts [1819]. „Der Schleswig-Holsteiner" 1930, S.528. "Treitschke: Anf. Værk, S. 414 f. - Wentzcke, Anf. Værk, S. 145, I64, 295 o. fl. Steder. ${ }^{6}$ Treitschke: Anf. Værk, S. 407 f. - Wentzcke: Anf. Værk, S. 89 f. o. fl. Steder. 7 Treitschke: Anf. Værk, S. 406 ff. - Wentzcke: Anf. Vark, S. 166 f. 
som virkede i demokratisk Retning, og navnlig var Luden utrættelig til at foreholde de andre tyske Stater det selvmorderiske i ikke at opfylde Forbundspagtens Forfatningskrav.

Graae vil ${ }^{1}$ i Overensstemmelse med Treitschke, der igen delvis bygger paa H. Leo, føre Lornsens frisindede Tanker tilbage til Paavirkningen fra den radikale Republikaner Dr. K. Follen ${ }^{2}$, der fra Efteraaret 1818 virkede som Privatdocent i Jena og søgte at skaffe sig Indflydelse hos de mest politisk interesserede blandt Studenterne ved at indgyde dem sin egen fanatisk republikanske Aand. I Modsætning til den almindelige Burschenschaftbevægelses mere eller mindre udprægede, romantiske Sværmeri for det Oldgermanske og særligt Tyske med det dertil svarende Had til alt, hvad der var Fransk, arbejder K. Follen sig nemlig $\mathrm{i}$ bevidst Tilslutning netop til de franske Friheds- og Lighedsideer bort fra de snævert nationale Bestræbelser, som han saa ned paa og drev Spot med, og mere og mere $i$ Retning af Tanken om en international Samling af alle revolutionære Kræfter og hemmelige, republikansksindede Forbund i Europa.

Med ham og hans Kreds, der er udgaaet fra Forbundet af de saakaldte "Sorte“ i Giessen, tilføres der da Burschenschaftbevægelsen i Jena et nyt Gærstof, der saa langt Follens Indflydelse naar, forstærker og radikaliserer Frihedskravene, men som ellers virker opløsende og splittende, baade naar det gælder Studenterbevægelsens indre Sammenhold og Arbejdet for dens nationale Maal.

$\mathrm{Nu}$ paapeger $\mathrm{W}$. Jessen, at de to betydningsfulde Breve, hvorfra ogsaa de tidligere nævnte Uddrag stammer, er skrevet henholdsvis 27. April og en af de førstc Dage i August I8I8, medens K. Follen som sagt først Efteraaret I8 8 skal have habiliteret sig i Jena ${ }^{3}$. Saa sent som den $\mathrm{I} 6$. December hører Lornsen aabenbart heller ikke til Follens fortrolige Kreds, hvad den lille baroktkomiske Skildring hos $\mathrm{H}$. Leo tydeligt viser. Ved en Fest, arrangeret af K. Follens Tilhængere paa Blüchers Fødselsdag, d. I8. Dec. I818, for at skaffe Follen Lejlighed til at paavirke et Par indbudte, unge tyske Fyrster, forarges Lornsen, der aabenbart ikke er indviet i Planen, over at se Follen tilsyneladende svigte sine Grundsætninger, og han gør da Skandale ved - med et Citat fra en af Follens egne Viser - at udbringe, ikke et Leve, men det modsatte, for

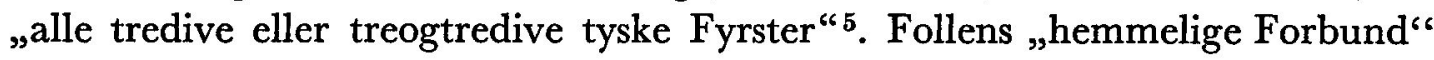

1 Graae: Anf. Værk, S. 66; Treitschke, Anf: Værk, S. 44I. ${ }^{2}$ Jvf. S. 66, Note ${ }^{6} .{ }^{3}$ Wentzcke: Anf. Værk, S. 3 I I. - H. Haupt: Anf. Værk, S. 29. - „Der Schleswig-Holsteiner" 1930, S. 4I 9 . 4. H. Haupt: Anf. Værk, S. 32 f. ${ }^{5}$ H. Leo: Aus meiner Jugendzeit. Gotha I88o. S. 181-183. Udførligt gengivet hos Graae, Anf. Værk, S. 67 f. 
af „Ubetingede" " synes iøvrigt ved nærmere Prøvelse at svinde ind til en dels meget snævrere og dels meget løsere Kreds, end Leo og Treitschke skildrer $\operatorname{det}^{1}$.

Allerede i Maj i 8ı8 dannede der sig, hvad vi nu vil kalde en Diskussionsforening, blandt de mere vaagne og modne Studenter; i Slutningen af Juni omdannedes den til den saakaldte „videnskabelige Forening “ 2 , voksede fra 20 til $5^{\circ}$ Medlemmer, - hvoriblandt en af de mest populære Professorer, den godmodige, noget uklare Filosof Fries, som var halvvejs Kammerat med Studenterne, og som til Brug ved Diskussionerne forfattede en politisk-idealistisk „Trosbekendelse", der mundede ud i Kravet om Tysklands Enhed med republikansk Rigsforfatning og lokalt Selvstyre ${ }^{3}$ - og samledes som før skiftevis i Medlemmernes Boliger til Diskussioner om Historie, Filosofi og Statsvidenskab (d. v. s. Politik). Endelig samledes atter godt 20 af Medlemmerne fra „den videnskabelige Forening “, da Vintersemestret 1818-19 begyndte, til en snævrere Forening med det samme Formaal. I Følge flere Deltageres Udsagn, hvoraf de fleste stammer fra Forhørene over politisk mistænkelige Studenter, efter at Regeringerne var blevet skræmt op ved Sands Mord paa Kotzebue, var Lornsen nu Medlem baade af „den videnskabelige Forening “ i Sommeren I818 og af den snævrere Forening den følgende Vinter; han betegnes af en af de andre Deltagere udtrykkeligt som en af "de mere rolige" 4 .

Ganske vist synes K. Follen ogsaa at optræde som Medlem allerede i den videnskabelige Forening ${ }^{5}$, saa at man, dersom denne Kilde holder stik, maa antage, at han dog er kommet noget tidligere til Jena, end W. Jessen, som selv anfører den, vil indrømme. Iøvrigt fremstilles i disse Forhør Formaalet med „Foreningen" selvfølgelig som ganske uskyldigt, hvad det vel ogsaa i det store og hele har været; det hævdes, at der ikke var Tale om det mindste hemmelighedsfulde: Enhver, der havde Lyst, kunde gaa med. Der var ingen egentlig Forening med Medlemsliste og Formand el. lign. Og hvad der maa anses for det vigtigste: Follen søgte vel at føre sine radikale Ideer til Sejr; men adskillige af de unge tog til Orde mod Follens fanatiske Ensidighed og Jesuitermoral, som til sidst havde til Følge, at Kredsen ved Paasketid I8 99 opløstes, uden at Follen skulde have vundet mere end en $2-3$ Stykker, som var villige til blindt at lyde ham ${ }^{6}$.

1 „Der Schleswig-Holsteiner" I930, S. 421. Isar herfra det følgende om „Foreningerne“" Jvf. P. Wentzcke: Anf. Værk, S. 306, hvorefter de „videnskabelige Selskaber" skulde være stiftede under Paavirkning af de "Sorte" i Giessen, og 3 II ff. ${ }^{2}$ P. Wentzcke: Anf. Værk, S. 308. 3 Anf. Værk, S. 312. "Der Schleswig-Holsteiner" 1930, S. 422. "Anf. Sted, S. 421. 'Anf. Sted, S. 422. - Wentzcke: Anf. Værk, S. 3 I I ff. 
Naar alt dette sammenfattes, kan man vel uden at gaa Sandheden for nær sige om Lornsens Udvikling i Jenatiden: Gennem Studenterlivet i Jena, Professorernes historisk-politiske Forelæsninger og endnu mere aktuelt politiske Tidsskriftartikler og endelig gennem Diskussionsaftenerne vinder Lornsen en Kærlighed til Friheden, som stemmer med hans inderste Natur, og som han derfor aldrig senere kan slippe, og en Sans for det offentlige Liv, for de Statsanliggender, som betyder mere end de enkelte Menneskers Skæbne; ogsaa dette bliver medbestemmende for hans senere Livsbane.

Hvilken Plads bliver der nu i alt dette for K. Follen? Er Lornsen slet ikke paavirket af ham? Jeg skulde mene jo; men et afgørende Svar herpaa vilde kræve en hel Specialundersøgelse. Kun enkelte Træk kan her antydes.

Der er i hvert Fald eet Omraade, hvor saavel Lornsen som de andre Studenter, hvad enten de hørte til Follens Omgangsfæller eller ej, vanskeligt vil have kunnet frigøre sig helt for Paavirkning af hans Aand, $\mathrm{i}$ højere eller ringere Grad. K. Follen og hans Brødre skrev Digte og Viser, der prædikede Had og Mord og Ødelæggelse over Fyrster og Tyranner og alle deres Lejetjenere ${ }^{1}$. Selv om de fleste af de umodne unge har slugt de blodtørstige Udgydelser raat og sunget dem uden Gnist af Tanke eller Vilje rettet mod at udføre det, de sang om, har disse friheds- og bloddrukne Ord ikke kunnet undgaa at give de unges Sind en Retning hen imod det voldsomme og løsrevne. Mens de store Ord jo nok hos de fleste tilsyneladende dunstede væk med den øvrige Rus, bundfældedes der dog altid noget, som hos enkelte uforvarende kunde stige frem paa ny, naar Anledningen dertil meldte sig. Det er en Linje fra K. Follens saakaldte „store Vise“, Lornsen ved Studentergildet, hvor han synes, Follen handler stik imod sin egen Overbevisning, slynger i Ansigtet paa Visens Ophavsmand ${ }^{2}$.

At Lornsen kan have noget hensynsløst i sit Væsen og sin Optræden, behøver man derimod ikke at gaa til K. Follen for at finde Forklaringen paa; hele Studenterlivet dengang forte det med sig, og Lornsen selv havde gode Anlæg herfor ${ }^{3}$. Det maa endvidere stærkt betones, at Lornsen, hvad alle Beretninger stemmer overens om, uanset sin Skarphed i Ord og bratte Beslutsomhed i Handling var godmodig af Natur og et Menneske, der trængte til at slutte sig nøje og fortroligt til sine Venner som til sine nærmeste Slægtninge 4 . K. Follen synes at have været en kølig, skarpttænkende Fanatiker med Hang til Begrebskløveri, for hvem den enkeltes Skæbne, om det saa var hans mest lærvillige Elevs, intet betød i

1 Treitschke og Graae anf. Steder. ${ }^{2}$ H. Leo: Anf. Værk, S. I82. - „Der SchleswigHolsteiner" r93o, S. 4 rgf. ${ }^{3}$ Notizen, S. 9 f. - Jansen: Anf. Værk, S. I 7 r. 'Jansen: Anf. Værk, S. 19o. - Brevene til Hjemmet vidner stærkt herom. 
Sammenligning med Spørgsmaalet, om Frihedens Sag vandt eller tabte derved ${ }^{1}$. Koldblodigt vurderede han Chancerne, hyttede sig selv, - for Sagens Skyld men saa roligt paa, at de unge, han havde ægget frem, gik deres Undergang i Møde ${ }^{2}$. K. Follens Indsats synes fortrinsvis at have været rettet mod det nedbrydende, mod at vække Hadet i de unges Sind og rydde alle moralske Hæmninger hos dem bort, for at gøre dem til brugbare Redskaber i den skaanselsløse, ja man fristes til at bruge Ordet, Klassekamp, som han stiler imod. Lornsen har fra første Færd haft en positiv Indstilling, i hvert Fald fra det Øjeblik han kommer til Jena og opdager, at Livet er mere end et Spil, at det er rettet mod et højere Maal, hvad han hidtil kun svagt har anet og slet ikke har levet efter.

Follens Jesuitermoral ${ }^{3}$ - eller er det blot den almindelige Studentermoral, den, der gælder, naar man ellers fra Studenterkorpsets Side udfægter sine smaa Skærmydsler med Myndighederne? - synes ogsaa at have smittet Lornsen og hans nærmeste Venner. Den 20. April I8I 9 afgiver Lornsen og fire andre „Forstandere" for det jenensiske Burschenschaft deres Fresord paa, at de til Forhørskommissionen har udleveret samtlige Papirer, der tilhørte det nævnte Burschenschaft, og at der efter deres bedste Overbevisning ikke eksisterede andre*.

Den 24. April skriver saa en af disse fem Studenter W. Wesselhöft til sin Broder i Berlin: „Tag Vare paa jeres Burschenschaft-Papirer, især dem, der angaar det almindelige Burschenschaft. Vi har udleveret alt, hvad der var uskyldigt, men tilintetgjort det øvrige ... I gør bedst $i$ at tilintetgøre alt, for at der ikke skal forekomme Modsigelser, og blot udlevere jeres Konstitution, men jo ikke Protokollerne“ 5 . Dette Brev bliver nu uheldigvis beslaglagt i Berlin, og giver jo straks Anledning til nye Forhør i Jena, d. 27. Aug.; men da er Lornsen over alle Bjerge, paa Vej hjem. De tilbageblevne søger at redde sig ud af det ved at hævde, at de havde forstaaet det, som om de kun skulde udlevere, hvad der vedrørte det jenensiske Burschenschaft, men ikke, hvad der blot angik fremmede Universiteter, som de nødigt vilde have draget med ind i Undersøgelsen, da det almindelige Burschenschaft jo alle andre Steder var forbudt, men trods det overalt havde konstitueret sig hemmeligt. En husker, at Lornsen og to af de andre dengang, d. 20. April, havde siddet ved et Bord og gennemgaaet en Række Breve, hvori de havde gennemstreget enkelte Navne og skaaret dem $\mathrm{ud}^{6}$.

Det ser ikke ud til, at man i Jena har gjort sig nogen Anstrengelse for at faa Lornsen fundet og forhørt paa ny; men det skulde vel ikke være denne Sag, der

1 Wit v. Dörring: Fragmente I, S. 35 f. ${ }^{2}$ Anf. Vark, S. 42. " „Der Schleswig-Holsteiner“ I930, S. 422. Anf. Sted, S. 528 f. ${ }^{\circ}$ Anf. Sted, S. 53r. Anf. Sted. 
har givet Anledning til, at man efter hans Optræden i 1830 vil paastaa, at han fra Tyskland har været efterlyst for „demagogiske Optøjer", men at den danske Regering har taget ham under sine beskyttende Vinger ved at erklære, at han var ansat $i$ Statens Tjeneste her? ${ }^{1}$

Hvis den førnævnte A. Haupt har Ret $i$, at det, der inden for den snævrere Kreds skilte Follen og hans nærmeste Tilhængere fra dem, der tog Afstand fra ham, var, at Follen og „de Ubetingede“ „ansaa deres [egen] Overbevisning for ufejlbarlig og [derfor] satte sig ud over alt det i Historien givne", mens de andre „ganske vist ligeledes ansaa det, som for Tiden var det bestaaende, for slet, men kun ventede en Bedring ved en rolig Byggen videre ("Hervorbildung") ud fra Livets egne Kilder“ („,aus dem Inneren des Lebens“) ${ }^{2}$, saa er det for den, der kender lidt til Lornsens senere Anskuelser og Handlemaade, ikke vanskeligt at se, hvilket af de to Standpunkter der har været bestemmende for hans politiske Livssyn og Gerning.

Er der noget, der kan bringe ham i Harnisk, saa er det den historiske Skoles Grundidé, der „altid har staaet for ham i et latterligt Skær“, at man ikke, naar man vil grundlægge noget nyt, uden videre maa vælge det, som man erkender for det mest hensigtsmæssige, men skal holde det Maal, man tilstræber, og hvad der hidtil har eksisteret af den Art, op imod hinanden, tage sit Udgangspunkt umiddelbart i det bestaaende og bygge videre derfra Trin for Trin. Nej, hans Mening er den, at, „hvad hver Generation erkender og erklærer for hensigtsmæssigt,

1 Fr. H. A. von Rumohr: Noch einige Worte veranlasst durch die Schrift des Canzeleiraths Lornsen ... Schleswig 1830, S. 5. Allerede ${ }^{29} / 11$ 1830 indrømmer v. Rumohr i et Privat-

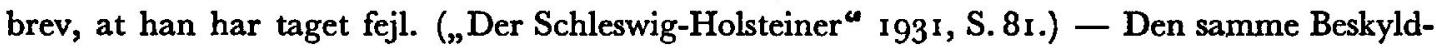
ning findes hos U.von Brockdorff: Betrachtungen, veranlasst durch die Schrift des Herrn Kanzleiraths Lornsen . . . Schleswig 1830, S. 36, - mens C. F. Schmidt-Phiseldeck: Ueber die neuerlichen Aufregungen in den Herzogthümern Schleswig und Holstein. Kopenhagen 1830, S. 5, giver Anklagen en videre Adresse, idet han uden at nævne Navne beskylder flere af Ophidserne (Binzer?, Olshausen?) for, at de har været indviklet i Forlegenheder, som de kun er blevet reddet ud af ved Kongens faderlige Omsorg og Mildhed. - A. Binzer: Die letzte Schrift des Herrn Conferenzraths u. Ritters von Schmidt-Phiseldeck . . . Braunschweig I 83 I, S. 9 f., protesterer mod Udtrykkene „Ophidsere“ og „Svindel“, men benægter ikke direkte selve Paastanden. - Derimod søger [A. J. L. Michelsen:] Sendschreiben an Herrn Dr. C. F. von Schmidt-Phiseldeck. Hamburg i83 I, S. 7, at rense Lornsen for enhver Beskyldning af denne Art, og Lornsen selv benægter i et Brev til Hegewisch, skrevet under Fængselsopholdet i Friedrichsort [Juli I83I] paa det bestemteste, at han nogensinde „har taget Del i demagogiske Optøjer eller skulde være blevet reklameret" (fra Udlandet). Jvf. Volquart Pauls: Uwe Jens Lornsens Briefe an Fr. H. Hegewisch, Schleswig 1925, Nr. 12, S. 27. 2 P. Wentzcke: Anf. Værk, S. 3 I 2 f. 
lad det saa afvige nok saa meget fra det bestaaende, det er historisk og intet Spring" 1 .

Og ikke mindre betegnende er hans Svar i I830 paa Chr. Paulsens Indsigelse mod hans Planer ud fra historiske Synspunkter: "Gamle historiske Forhold angaar os ikke, saadan vil vi nu have det; hver Tid (maa og) skal danne sig sin egen Tilstand. ... 2 .

Paa eet Punkt har Lornsen dog maaske især lært af Follen. Naar Follen kalder den Mand fejg, der i Kampen for sine Idealer bøjer af og tilpasser sine Idealer efter det, der synes opnaaeligt, i Stedet for at lade sig anspore af Vanskelighederne til at spænde sine Kræfter endnu mere og stræbe endnu højere, i fast Tro paa, at det er Idealet, der er det sande, at det er det, der repræsenterer den Virkelighed, som ogsaa i Livet nok skal blive den herskende til sidst ${ }^{3}$, saa vil dette Ord til andet kunne bruges om Lornsens senere Stræben. Og naar Follen ligeledes hævder, at den, der føler sig overbevist om, at han af „en sædelig Nødvendighed" drives til Handling, maa rive sig løs fra alle hæmmende Baand, af hvad Art de end er, ogsaa Hensynet til ens Nærmeste, og at, naar man staar over for en saadan højere Nødvendighed, alle Midler er tilladt4, uanset, hvad der er gældende Moral, saa er det ikke fri for, at Lornsen har handlet ud fra den Aand i lige saa høj Grad, som Follen selv gjorde det.

Skal man uddrage Resultatet af det her anførte, maa det blive følgende:

Det kan ikke bevises, at Lornsen har hørt til K. Follens „ubetingede“ Tilhængere, som aldrig udgjorde noget stort Tal; men lige saa vanskeligt vil det blive at godtgøre, at han skulde have været blandt dem, der inden for den snævrere Kreds har taget bestemt Afstand fra Kærnen i Follens politiske Grundanskuelse. I Betragtning af Lornsens udprægede Selvbevidsthed kan man paa Forhaand vanskeligt tænke sig, at han, der var tre Aar ældre end $\mathrm{K}$. Follen, skulde være traadt i noget egentligt Elevforhold til ham, som Wit von Dörring ${ }^{5}$ gjorde det, og der vilde ikke være noget mærkeligt i, om Follens anmassende Optræden til syvende og sidst havde virket lige saa frastødende paa Lornsen, som paa flere af Lornsens nære Venner ${ }^{6}$. Der findes ikke mindste Antydning af, at Lornsen skulde have været indblandet i nogen hemmelig, revolutionær Sammensværgelse, om der paa det Tidspunkt overhovedet har eksisteret noget, der kunde gøre sig

1 Volquart Pauls: Anf. Værk, S. 34, Nr. 15. [Friedrichsort], 8/8 [1831]. ${ }^{2}$ H. N. Clausen: Slesvigeren Chr. D. Paulsens Livshistorie i Omrids. Kbh. 1857, S. 19. ${ }^{3} \mathrm{~K}$. Follen paa et Stambogsblad i Jena; H. Haupt: Anf. Værk, S. 30 f. Wit v. Dörring: Fragmente I, S. 42. P. Wentzcke: Anf. Værk, S. 306. - H. Haupt: Anf. Værk, S. 31. ' Wit v. Dörring: Fragmente I, S. 42. 'Wentzcke: Anf. Værk, S. 3 I 2 f. - Wilh.Jessen: „Der Schleswig-Holsteiner" 1930, S. 422. 
fortjent til dette Navn. Men hvad man kan fastslaa med saa stor Sikkerhed, som der nu engang efter Sagens Natur lader sig skaffe, er, at Lornsen i hvert Fald i den snævrere Diskussionsforening maa have hørt Follen udvikle sine Meninger, og at de politiske Grundanskuelser, udfra hvilke de to Mænd taler og handler, paa flere afgørende Punkter falder meget nøje sammen. Skønt Lornsen er den ældre af de to, er det da næppe uberettiget at mene, at Follen, som er udgaaet fra et Advokathjem, og hvis aandelige Horizont baade har været større og tidligere er blevet udvidet, mens han i Retning af Skarphed og Klarhed i Tanken mindst har været Lornsens Ligemand, er den, fra hvem Paavirkningen udgaar, og at Lornsen bevidst eller ubevidst har været den modtagende ${ }^{\mathbf{1}}$.

Ogsaa i Lornsens Sind trænges Burschenschaftbevægelsens tysk-nationale Maal da noget tilbage, mens Frihedsideerne en Tid lang bliver den stærkeste Strøm og gør det vanskeligt for ham at finde sig til Rette i de hjemlige, stillestaaende Forhold. Saa tvinger de ydre Forhold ham til ogsaa at lade Frihedstrangen bundfælde sig i Dybet af Sindet, og først da den i I 830 er blevet udløst, er det, som om de første Studenterdages tysk-nationale Begejstring under Fængselstidens Læsning og Eftertanke for Alvor bliver stærk og levende igen ${ }^{2}$.

Da Lornsen kort før sin Afrejse skal gøre op for sig selv og sin Fader ${ }^{3}$, hvad Jenaopholdet har betydet for ham, kommer han til det Resultat: At Livet har faaet et højere Værd for ham, at han derved er blevet reddet fra at styrte i den Afgrund, hvor han ellers uhjælpeligt vilde være havnet, om han var vedblevet at betragte det blot som et Spil, og endelig, at han har faaet et Maal at stræbe imod, som han vil vie hele sit Liv til, og dette Maal er: Friheden — „Friheden i hele dens Omfang, uden hvilken intet Sandt, Stort og Skønt i Livet kan opstaa og bestaa“ "4. Til at løse den Opgave skal ogsaa Retsvidenskaben være ham et godt og brugbart Middel, og derved bliver det ham ogsaa muligt, skriver han til Faderen, at overvinde sin Uvilje mod den.

„Med Fortrøstning, Mod og Fasthed gaar jeg nu Fremtiden i Møde" ${ }^{5}$. Det er Lornsens selvsikre Afskedsord, da han staar i Begreb med at forlade det Samfund, der har præget ham for Livet og rakt ham de skarptslebne Vaaben, der skulde gøre det muligt for ham at øve den Gerning, hans Sind higede mod, selv efter at han havde maattet vente i over ti Aar, før hans Tid var inde.

1 Wilh. Jessen (Anf. Sted, S. 419-422) gør sig Umage for at rense Lornsen for enhver Mistanke om, at han skulde have gaaet i Lære hos K. Follen. Som det vil ses af ovenstaaende kan jeg ikke helt slutte mig til ham. '3 Brev til Faderen, d. $16 / 3$ 1819. Jessen: Briefe, S. $5^{8} \mathrm{f}$. 4 Anf. Sted, S. 59. 5 Anf. Sted. 


\section{CHRISTIAN PAULSEN}

Den unge Professor, der i April I 826 drog fra Roskilde til Kiel for at tage en Gerning op som Lærer i Retsvidenskab ved Universitetet der, følte sig som en saare lykkelig Mand. Fra sine mange gode Venner paa Sjælland drog han nu med sin elskede Brud, som han en Tid lang næsten havde mistvivlet om at kunne vinde, til deres nye Hjem for at vie sine Kræfter til et Arbejde i og for sin snævrere Hjemstavn. Da der faa Aar efter aabner sig Mulighed for ham til at opnaa en baade mere anset og bedre lønnet Stilling ${ }^{1}$, afviser han Tanken, fordi han føler, at der paa ham hviler en Opgave af særlig Art, som han ikke har Lov til at svigte.

„Min Embedsstilling“, skriver han, „har den vigtige Betydning for mig, at jeg bidrager til at gøre de to Hoveddele af Riget mindre fremmede for hinanden, ved at fremhæve mit nærmere Fødelands (Slesvigs) danske Grundbestanddele, og derved at vise Slægtskabet med Kongeriget, medens jeg til samme Tid søger upartisk at udvikle det Tydske i dets Aand" " Lignende Tanker kommer frem i Slutningen af Fortalen til det første Skrift, hvormed han offentligt tager til Orde for det dansktalende og dansksindede Sønderjyllands Ret: Ueber Volksthümlichkeit und Staatsrecht des Herzogthums Schleswig ${ }^{3}$, imod de Anskuelser, som Lornsen og hans slesvig-holstenske Meningsfaller havde udviklet $\mathbf{i}$ deres Pjecer.

Han fremhæver her, hvordan han, der i Kraft baade af sin indre og sin ydre Livsførelse føler sig knyttet til hele Fædrelandet (altsaa ikke bare enten til den tyske eller til den danske Del af det), føler det „som sin skønneste Opgave at mildne de Modsætninger, der unægtelig er til Stede mellem Hertugdømmerne (og da især mellem Holsten) og Kongeriget, hvad der ene og alene kan opnaas, ved at de to Dele gensidigt bliver bedre kendt med hinanden, og ved at de gensidigt bedømmer og behandler hinanden med den yderste Retfærdighed". Han slutter da med det Ønske, der ligger ham saa stærkt paa Hjerte, at det maa lykkes ham at fremme Velvilje og Samfølelse mellem Tyske og Danske i den fælles Stat.

Og som et indtrængende Vidnesbyrd om, at det er i Lyset af disse Fortalens sidste Ord hele Skriftet skal forstaas, virker Underskriften: Kiel, Juleaften 183 I ${ }^{4}$.

1 1830 ved Københavns Universitet, $183 \times$ Kaldelse til Dorpat paa overordentlig gunstige Vilkaar i økonomisk Henseende. Jvf.: Forfatterens Livshistorie i Omrids af Dr. H. N. Clausen. S. I5 (Chr. Paulsens samlede mindre Skrifter I, Kbh. 1857). Ogsaa udgivet som selvstændigt Skrift samme Sted med Titel: Slesvigeren Chr. D. Paulsens Livshistorie i Omrids. Citeret: Livshistorien. Anf. Sted. ' Skrevet Efteraaret 1831. Fortalen sluttet Juleaften 1831; udgivet Kiel Jan. 1832. Her citeret efter Samlede Skrifter II, S. 353-429. “ Anf. Værk. Samlede Skrifter II, S. 36 I. 
Og da han i 1848 , fordrevet fra sit Hjem og sin Gerning af Oprøret, lader sin Røst høre ved Københavns Universitet ${ }^{1}$, som den første Slesviger, der paa dette Sted holder Forelæsninger over den særlig slesvigske Ret ${ }^{2}$, og søger at klarlægge for Tilhørerne de personlige Forudsætninger, som har ført ham derhen, hvor han nu staar, da mindes han ogsaa de Tanker og Følelser, hvormed han som ung tog sin Gerning op i Kiel. Naar han, den iøvrigt rent tyskuddannede Mand, i sin Tid havde ønsket at afslutte sin juridiske Udannelse ved Københavns Universitet, var det ikke blot som Følge af en direkte Tilskyndelse fra Gøttingerprofessoren Eichhorns Side, men Chr. Paulsen gjorde det bevidst med den Plan for $\emptyset_{\mathrm{je}}$ derigennem at kunne „bidrage til at gjøre den danske og nordiske Ret tilgjængeligere for den tydske Retsvidenskab“, og, fortsætter han, „da jeg omsider blev ansat ved Kiels Universitet som Professor i den danske og tillige den slesvig-holstenske Ret, turde jeg nære det Haab ogsaa at kunne forplante dansk Retsvidenskab derhen, saa at Hertugdømmerne skulde danne Broen for tydsk og nordisk Videnskabelighed ogsaa i denne Henseende ${ }^{3}$. Naar Chr. Paulsen her ønsker Samarbejde ikke blot mellem tysk og dansk, men mellem tysk og nordisk Videnskab, er det ikke et tilfældigt Udtryk, der er løbet ham i Pennen. Saa tidligt som 1826 føler han „hele det gamle Norden“ som den danske, norske, svenske og islandske Oldgranskers Fædreland, som sit Fædreland i videre Forstand, paa samme Maade, som han med Forstaaelse og Beundring ser hen til, at der af tyske Videnskabsmænd er skabt et fællestysk aandeligt Fædreland, uanset alle smaastatslige Skel ${ }^{4}$. Og dette Maal, som han i det længste holder fast ved, Slesvig ikke blot som Bindeled mellem Danmark og Holsten, statspolitisk set, men det langt dybere: Slesvigerne som Formidlerne mellem de to Naboer, Nedersakserne og Danerne, mellem tysk og nordisk Folkeejendommelighed ${ }^{5}$, Slesvig som Folkebroen, hvor tysk og nordisk Aand mødes og gensidig befrugter og beriger hinanden, dette Maal stod dengang ingenlunde for ham som en virkelighedsfjern Drøm, men som noget, der var godt paa Vej til at virkeliggøres. „Dette Haab syntes i det første Femaar ${ }^{6}$ fra I $_{2} 6-$ - 83 I at gaa i Opfyldelse. Det lod virkeligen, som om de tydske og danske Rigsdele vilde kunne nærmes hinanden ved Udbredelsen af Bekjendtskab med den danske Literaturs og Videnskabeligheds forskjellige Grene; men da tog pludseligen efter den franske

1 21/11 1848; Samlede Skrifter I, S. 694; opr. trykt i „Dannevirke“, 10. Aargang, Nr. 156. ${ }^{2}$ Anf. Sted, S. $698 .{ }^{3}$ Anf. Sted, S. 695. "Fra hans Afhandling: Om Gavnligheden af Kundskab om Oldtiden i Almindelighed og om den aldre Retstilstand i Særdeleshed (Opr. trykt i det nordiske Oldskrift-Selskabs Tidsskrift, Bd. 2, Kbh. 1826). Samlede Skrifter I, S.6o. 5 Samlede Skrifter II, S. 426 f. Paulsen har det latinske: lustrum. Samlede Skrifter I, S. 695. 
Revolution [Julirevolutionen 1830] Folke- og Statslivet et nyt Opsving, og den danske Regjering greb ikke det rigtige Middel til at holde Staten sammen ved en dengang mulig fælleds fri Forfatning". ${ }^{1} \mathrm{Ja}$, $\mathrm{i}$ disse unge Aar haaber Chr. Paulsen paa en endnu mere omfattende Udsoning af hidtil modstridende Interesser. Vel maa han indrømme, at med Hensyn til Folkeretten var Menneskene ikke paa langt nær naaet saa vidt som paa de fleste andre Omraader ${ }^{2}$, i Retning af at opfylde deres Bestemmelse her paa Jorden „at skride frem til en højere Fuldkommenhed" 3 . Naar det gjaldt Staternes indbyrdes Forhold, var man ikke naaet saa forfærdelig langt ud over Naturtilstanden, hvor gensidig Frygt og Mistro var de Følelser, der bestemte enhvers Optræden over for andre, og hvor man søgte at opretholde sin Magt ved kun at tage Hensyn til sin egen Sikkerhed og Interesse. Og han indsaa ogsaa nok, at den interstatslige Magtfaktor, der maatte skabes, for at man virksomt kunde tilbagevise ethvert Brud paa en Folkeret, der byggede paa Retfærdighed, vilde være saare vanskelig at indrette. Men trods alt er hans Syn paa den stigende Linie i Menneskehedens Udvikling, „Fuldkommengørelsen ", 4 saa lyst, at han i den hellige Alliance øjner den første svage Spire til et Folkenes Forbund, selv om han langtfra er blind for, hvor meget der maa ændres i de enkelte Stater, før man for Alvor kan haabe noget af dette Forsøg ${ }^{5}$.

Naar Chr. Paulsen i 1848 , da ethvert, selv det mindste Resultat af hans mangeaarige Taalmodighedsarbejde for at bygge Bro mellem de folkelige og politiske Modsætninger synes at være styrtet sammen og tilintetgjort for stedse, skal gøre sig klart, hvad det er for Kræfter, der paa saa afgørende en Maade har krydset hans Stræben, ja umuliggjort Haabet om, at et videre Arbejde i den Retning vil bære mindste Frugt, saa nævner han Julirevolutionen. Og ikke uden god Grund. Det er Aaret 183o, der ogsaa herhjemme sætter Skel paa det politiske som paa det nationale Omraade, og den fjernere Anledning hertil maa utvivlsomt søges i Julirevolutionen og de Opstande, den afføder rundt om i Europa.

Men naar dens Følger straks i første Omgang blev saa skæbnesvangre for det nationalpolitiske Spørgsmaals Udvikling inden for det danske Monarki, saa skyldes det $\mathrm{i}$ ganske overvejende Grad en enkelt Mand, Friseren fra det velstaaende Kaptajnshjem i Keitum paa Sild, Uwe Jens Lornsen.

1 Anf. Sted. 2 Anf. Sted, S. 57 (fra ovennævnte Afhandling: Om Gavnligheden osv.). ${ }^{3}$ Anf. Sted, S. 58 . Anf. Sted. En af Chr. Paulsens Yndlingstanker, der atter og atter dukker op paa mange forskellige Steder. Jvf. f. Eks. Livshistorien, S. 1o. - Samlede Skrifter I, S. 6 f. og S. $68 . \quad 5$ Anf. Sted, S. 58 . 
Som en fejende Foraarsvind for hans frimodige $\operatorname{Ord}^{\mathbf{1}}$ hen over Landet, sprængte de første dybe Revner i det enevældige Styres Isdække, der allerede var begyndt at udhules saa smaat indvendigt fra, og afløstes saa hurtigt af tilsyneladende stille og smukt Vejr igen.

Ogsaa i Chr. Paulsen havde Frihedstankerne slaaet Rod. I det allerede nævnte Skrift fra 1832 bekender han, at ogsaa han paa tyske Skoler og Universiteter har levet med i Frihedsaandens Sejrsgang fra første Begyndelse og af ganske Hjerte, uden at dette dog har hindret ham $i$ at bevare sin medfødte Følelse af at høre til det danske Folk ${ }^{2}$.

Som Studieaarene i Jena gjorde U. J. Lornsen til glødende Frihedsven, har Chr. Paulsens Skolegang i Schnepfenthal, Gotha og Lybæk og hans Universitetstid i Gøttingen, Berlin, Heidelberg og Kiel ${ }^{3}$ ladet ham leve med i de Strømninger, som rørte sig i det unge Tyskland, og vakt en lignende Begejstring for Frihedstankerne $\mathrm{i}$ hans Sind. Lidt ilter som han var af Gemyt, kunde han i de unge Aar tage Sagen „med Ynglingens Opbrusen og Letsindighed"4 og komme i Fyr og Flamme, naar han mødte overlegne Advarsler mod „alle demagogiske Omdrifter".

I et Brev til sin Ven, cand. jur. Abrahams., skrevet i Kiel d. 18. Juni 1820, beretter han om en politisk Diskussion med Professor Stenersen ${ }^{6}$. Ud fra den store Skandale, som Opdagelsen af den Finansdeputerede, Konferensraad Birchs Bedragerier havde vakt ${ }^{7}$, saa vel som fra de mange andre Underslæb hos Statens Embedsmænd, der opdagedes i de Aar, søgte Chr. Paulsen at godtgøre, at noget saadant ikke vilde have været muligt, „hvis en godtvalgt Folkefortrædning havde gaaet den gode, nu naturligvis sig ulykkelig følende Konge tilhaande $i$ at controlere hans Embedsmænd, hvad aldrig saa godt kan skee ved høiere Embedsmænd", mens „det værste er, at de høieste Embedsmænd, hvilke have det hele under sig, slet ikke controleres, saa at under deres Egennyttighed hele Folket maa lide". Han haaber inderligt, at denne sidste Skandale maa have „bidraget $\mathbf{i}$ at gjøre det flere indlysende, at en Forandring i Bestyrelsesmaaden var det nødvendigste og eneste Medicin for vore syge Finantser".

${ }^{1}$ Ueber das Verfassungswerk in Schleswigholstein. Kiel 1830. Gedruckt bei C. F. Mohr. Jvf. „Die Heimat", Jahrg. 4I (193 r), S. r20. Jvf. forrige Afhandling. ${ }^{2}$ Samlede Skrifter II, S. 358. ${ }^{3}$ Livshistorien, S. 5. - Samlede Skrifter II, S. 358. ${ }^{4}$ Brev til Professor KolderupRosenvinge, Kiel ${ }^{27} / 12$ 1830. Kgl. Bibl. Ny kgl.Samling 3 ror $4^{\text {to. }}$ ' 5 Den senere Professor i Fransk og Notarius publicus N. C. L. Abrahams (1798-1870). Venskabet er sluttet i Heidelberg under Abrahams's Udenlandsrejse, Eftersommeren 18 r 9. Jvf. N. C. L. Abrahams: Meddelelser af mit Liv, Kbh. 1876, S. I04. ${ }^{\circ} \mathrm{Kgl}$. Bibl., Abr. 7. - St. Johs. Stenersen (1789-1835), Prof. theol. i Christiania. 7 Marcus Rubin: Frederik VI's Tid. Kbh. 1895, S. 236. 
Men han protesterer paa det heftigste mod af den Grund at blive kaldt Demagog.

„Er det ikke afskyeligt, at de, som føler sig gjennemtrængt af den høieste Fædrelandskjærlighed, som føle en hellig Iver i deres Bryst at fremme saa meget de formaae, Fædrelandets Vel, men netop derfor ønske og arbeide paa Forandringer, hvis Nødvendighed de ere overbeviiste om, for at komme ud af den gamle trævne Slendrian, at disse kaldes Demagoger, Revolutionære? Dette Navn passer dog kuns paa de faae, (hvis Tilværelse jeg hverken vil eller kan nægte) hvilke uden alt Hensyn paa den bestaaende Tilstand agte paa engang at indføre $i$ Virkeligheden deres philosophiske Bygninger paa en Maade hvilkensomhelst det end var."

Er der maaske næppe saa voldsom en Glød i Chr. Paulsens Kærlighed til Friheden som i U. J. Lornsens, saa flammer den heller ikke op i saa urolige Blaf (med tilsvarende Pauser, hvor Flammen truer med at slukkes) snart $i$ den ene, snart $i$ den anden Retning. Mens Lornsen fra Tid til anden bliver begejstret for at tjene Frihedens Sag snart paa Haïti eller i Nordamerika $^{1}$, snart $i$ den græske Frihedskamp ${ }^{2}$, før han endelig efter ti Aars Ventetid gør sit store Fremstød paa hjemlig Grund, saa er al Chr. Paulsens Higen lige fra Studieaarene i Tyskland rettet mod at komme til at tjene sit Fædreland ${ }^{3}$.

Og det er ogsaa dettes Vel han tror at kunne fremme ad Frihedens og Forfatningsudviklingens Vej, baade naar det gælder det større Fædreland Danmark og den snævrere Hjemstavn Slesvig.

„Saadan en Forandring [Forfatningsf.] er ogsaa den eneste lovlige Vei at bringe mit specielle Fædreland atter i det gamle Forhold til vort fælleds Fædreland, vort elskede Danmark, at forvandle Hertugdømmet Slesvig under Hertug Friedrich atter i Sønder-Jylland under Kong Frederik af Danmark, og gjerne vilde visligen de fleste Sønderjyder møde med Nørrejyderne, Fyenboerne og Sjellandsfarerne paa Danmarks Althing" for sammen med Regeringen at pleje Raad om Danmarks Vel4.

Mens U. J. Lornsen hjemmefra hverken har taget nogen stærkt udpræget Velvilje eller Uvilje mod Danmark i Arv, og derfor helt kan lade sig fylde af det nye, der møder ham i Kiel og Jena og i Omgangen med hans slesvig-holstensk prægede jævnaldrende ogsaa i København, saa er Chr. Paulsen gennem sin Slægts og sin Fødebys Traditioner og sine egne Barndomsoplevelser ved utallige

1 Wilh. Jessen (og G. E. Hoffmann): Uwe Jens Lornsens Briefe an seinen Vater. Breslau 1930, S. 41, 50 f. ${ }^{2}$ Anf. Vark S. 74 ff. ${ }^{3}$ Livshistorien, S. 7. ${ }^{4}$ Brevet til Abrahams. 
Baand knyttet til det danske Fædreland ${ }^{1}$ og dets Konge, som han uden at forfalde til overdreven Smiger viser skyldig Erbødighed ${ }^{2}$. Derfor kan Frihedsbegejstringen, der hos dem begge udspringer fra eet og samme Kildevæld, lede U. J. Lornsen til at kræve et frit Slesvig-Holsten, men Chr. Paulsen til at ønske et Danmark, som ad Frihedens Vej atter har knyttet Sønderjylland til sig.

Frihedstrangen har hos Chr. Paulsen aldrig været af den primitive Styrke, et saadant Grundelement $\mathrm{i}$ hele Personligheden som hos U. J. Lornsen.

Men som alle Frihedsvenner glæder han sig over Efterretningerne om Julirevolutionen i Frankrig og skriver i sin Dagbog ${ }^{3}$ : „I Politiken har Franskmændenes tappre Forsvar af deres Frihed, og deres hurtige Oprettelse af en ny fast Statsorden straks efter de heltemodige Pariseres tre Kampdage den 27.-29. Juli vakt min som alles høieste Deltagelse og Begeistring. Hvilket gavnligt Exempel paa Folkenes Fordring af en retlig Fremgangsmaade fra Statsmagtens Side."

Chr. Paulsens Stilling til U. J. Lornsen og hans Forfatningsplaner i Oktober - November 1830 har i Hovedsagen været kendt, siden H. N. Clausen i 1857 byggede sin Skildring af Chr. Paulsens Liv og Gerning 4 paa Grundlag især af Paulsens egne Breve og Skrifter og ganske særligt af hans Dagbøger, hvoraf to nu tilhører det kgl. Bibliotek ${ }^{5}$. Fra Dagbogen (indført under Datoen: Søndagen den I4de November) er det Afsnit hos H. N. Clausen taget ${ }^{6}$, der giver os Paulsens Opfattelse af de to unge, frisindede Slesvigeres Møde, hvor det danske og det nyere slesvig-holstenske Standpunkt for første Gang tørner haardt sammen paa den politiske Kampplads.

Chr. Paulsen lægger ikke Skjul paa, at Lornsens ,grundige og overbevisende Klarhed "7 og imponerende Personlighed ogsaa i første Omgang har gjort et dybt Indtryk paa ham, saa at Ungdommens Frihedsideal træder frem for ham paa ny „, liflig Glands“ ${ }^{8}$. Allerede Hensynet til den gamle Konge dæmper dog straks Iveren noget ${ }^{9}$, og hvad der især hjælper Chr. Paulsen til at komme „til fuldkommen Klarhed og Enighed“" med sig selv, er den „gavnlige Indflydelse“, som det har haft paa ham, at han „som i næsten alle Anliggender, saa og i dette“ har "staaet $i$ den nærmeste Berøring“ med sin gode Ven og ca. I4 Aar ældre

1 Livshistorien, S. 4 og Anm. 2. - Ueber Volksthümlichkeit osv. (1832), i Samlede Skrifter, II, S. 360 . - Indledningsforedrag Kbh. ${ }^{21} / 11$ I848, Samlede Skrifter I, S. 694 f. ${ }^{2}$ Livshistorien, S. 8. ${ }^{8}$ Søndagen den 5 te September (1830). ${ }^{4}$ Se S. 77, Note I. ${ }^{5}$ D. kgl. Bibliothek. Ny kgl. Samling 2897 4to. ' Livshistorien, S. 18 f. $\quad$ ' K. Jansen: U. J. Lornsen. Kiel 1872, S. 223. Lornsens selvbevidste Udtalelse i Brevet til Kancellipresidenten, Grev O. Moltke, om sine egne Evner. ' Livshistorien, S. 18. ' Anf. Sted. 
Kollega Niels Falck ${ }^{1}$, og den „Rolighed og Besindighed, hvormed han veiede Midlerne for den jo ogsaa af ham yndede Sag“2.

Det skyldes da utvivlsomt ogsaa i nogen Grad den besindige, roligt prøvende Falcks Indflydelse, at Chr. Paulsen, da de bevægede Dage i Slutningen af Oktober og Begyndelsen af November 1830 sætter ind, „er blevet betænksommere og mener, at man ikke skal ved alle muelige Midler ville forandre en taaleligen god Tilstand for en haabet bedre, og at man bør betænke, at Idealet ikke paa een Gang lader sig indføre i Virkeligheden“, selv om han stadig „holder et godt repræsentativt Monarchie for et uskatteerligt Gode og for vor Nutids store Maal" 3 .

Det er iøvrigt ikke blot over for Chr. Paulsen, at Falck har øvet en beroligende og afdæmpende Indflydelse $i$ hine afgørende Dage. Paa Falck ${ }^{4}$ og dermed paa hele det noget ældre Slægtled af slesvig-holstenske Liberale i Kiel er Lornsens bydende Optræden og overlegne Veltalenhed, der bøjer de yngre og mindre selvstændige ${ }^{5}$ ind under hans Vilje, spildt.

Og det er da i første Række Falck, der har Eren (eller Skylden) for, at Lornsenrøret mistede sin Stødkraft, inden det endnu var naaet videre end til Starten, selv om allerede den flensborgske Købmandsstands Holdning gjorde Lornsen usikker og fik ham til at opgive sin første Plan om et Massemøde i Kiel ${ }^{\mathbf{6}}$. Falck og den ældre Liberalismes Repræsentanter nægter at gaa med til den paatænkte almindelige Petition, underskrevet af en større Kreds af Mænd fra begge Hertugdømmer, Falck, dels fordi han overhovedet var imod en Petition paa det Tidspunkt, dels fordi han fandt denne Form for Petition ulovlig ${ }^{7}$. Den kunde ikke bringes i Overensstemmelse med Patentet af I I. Sept. I 795, hvorefter man skulde vende sig med alle Bønner og Begæringer til sin Øvrighed eller sine Foresatte og ikke gøre fælles Sag med andre for at trodse noget igennem, men vogte sig omhyggeligt for alt, hvad der kunde tage sig ud som Opstand, og ikke lade

1 Om Falcks politiske Betydning jvf. især W. Carstens: Niels Falck. Schlesw.-holst. Kunstkalender 1924, S. 71-73, og Carl Petersen: Nicolaus Falck und die Entstehung des schlesw.holst. Gedankens. Veröffentl. d. Schlesw.-holst. Universitätsgesellschaft. Nr. Io. Breslau 1926. S. 1-102. ${ }^{2}$ Citaterne fra Brevet til Professor Kolderup-Rosenvinge, Kiel ${ }^{27} / 12$ 1830. ${ }^{3}$ Anf. Sted. - Ang. Chr. Paulsens politiske Anskuelser, jvf. Fortalen til Skriftet: Ueber Volksthümlichkeit osv., Samlede Skrifter II, S. 355-358. 4 Jvf. Falcks Indberetning til Kancellideputeret J. Fr. Jensen, Zeitschrift, Bd. 58. (1929), S. 586-588. - Sønderj. Aarb. r9or, S. 220 ff., jvf. S. 182 og 202. 5 Georg Hanssen: Lebenserinnerungen. Zeitschrift, Bd. 40. (1910), S. 42. K. Jansen: Anf. Værk, S. 221. - Paul Richter: Aus der schlesw.-holst. Verfassungs- und Verwaltungsgeschichte, Zeitschrift, Bd. 58. (1929), S. $4^{87}$. ${ }^{6}$ K. Jansen: Anf. Værk, S. 220. 7 Zeitschrift, Bd. $5^{8}$. (1929), S. $5^{87}$. 
sig forlede af Oprørere ved Overtalelse eller forføreriske Skrifter til Fejltrin eller Forseelser ${ }^{1}$.

Da Lornsen opgiver Planen om det store Møde i Kiel og vender om fra Flensborg med uforrettet Sag, har han vel nok allerede forspildt Muligheden for en Sejr; men da han giver efter for Falcks Indvendinger og gaar med til, at lokale Petitioner til den stedlige Øvrighed skal træde i Steden for den ene fælles, da besegler han uden at vide det sit eget Nederlag. Nu kan Regeringen trøstigt gribe ind med de kendte og prøvede Midler, hvormed man lykkeligt afværger alle Petitioner, undtagen een fra Sild. Offentligt udnytter man Folkets Hengivenhed for Kongen og slaar paa, at man dog sikkert ikke vil gøre noget, som maa volde ham Sorg ${ }^{2}$; men i et Reskript fra det slesvig-holstenske Kancelli til samtlige Embedsmænd af 23. Nov. bliver de alle kraftigt mindet om deres Pligt til at modvirke fælles Petitionsbevægelser af utilladelig Art ${ }^{3}$.

Under dette Tryk fra oven er det ikke engang muligt at faa Magistrat og Byraad i Kiel til at indsende nogen Petition, skønt et ret stort Antal af Borgere, hvoriblandt ogsaa Chr. Paulsen, ${ }^{4}$ med Falck og Advokat Balemann i Spidsen har andraget derom. Dette Skridt er dog nærmest udsprunget af Frygt for de mulige Følger, hvis de unge „Demagoger" af Lornsens Type beholder Førerskabet og faar Lov at løbe Linen $\mathbf{u d}^{5}$. Herved bliver det ogsaa lettere forstaaeligt, at Borgmester Wieses meget behændige Tale og Stadtsyndicus Dreyers noget grovere Argumenter ${ }^{6}$ virker saa overvældende, - maaske ikke mindst, fordi man mere end aner, hvem der taler igennem deres Munde - at ikke een Stemme løfter sig for at hindre, at Tanken falder uden mindste Modsigelse, og det, skønt flere af Underskriverne har Sæde i Byraadet?

Ejendommeligt er det, at Falck, som i 1830 ikke kan forene det med sin Samvittighed at gaa med til at indsende en Fællespetition, i i 8 I 8 ikke blot har underskrevet en saadan, men selv forfattet Udkastet til den. I823 aftrykker han den som et historisk Dokument $\mathrm{i}$ sit Staatsbürgerliches Magazin ${ }^{8}$. Den omtales atter i samme Tidsskrift $\mathrm{X}, \mathrm{I} 83^{1^{8}}$, og for nylig har Paul Richter fremdraget den

1 Chronologische Sammlung der im Jahre 1795 ergangenen Verordnungen und Verfügungen. Nr. 46, S. 82-84. Kiel r 796. T. F. Wiese und A. Dreyer: Vorträge in der Versammlung des Magistrats und der deputirten Bürgerschaft der Stadt Kiel am 26sten November 1830 über die an dieselben gerichtete Bitte einer Anzahl Kieler Einwohner um Einreichung einer Petition. (Trykt som Manuskript, Kiel 1830), S. 9. ' ' Paul Richter: Anf. Sted, S. 496. ' 1 Livshistorien, S. 19. ${ }^{5}$ Zeitschrift, Bd.58. (1929), S. 587. - Sønderj. Aarb. I9or, S. 220 f. og 224 f. ' Wiese u. Dreyer: Anf. Skrift, S. 9 ff. og 16 ff. 7 Wiese u. Dreyer: Anf. Skrift. Paul Richter: Anf. Sted, S. 499-502. B N. Falck: Staatsbürgerliches Magazin III. Schleswig 1823, S. 210-213. S. $840-842$. 
i sin Afhandling om den slesvig-holstenske Forfatnings- og Forvaltningshistorie ${ }^{\mathbf{1}}$; men ellers leder man forgæves efter andre Meddelelser om dens Modtagelse og videre Skæbne. Da Politimester Christensen i Kiel henviser til den over for det slesvig-holstenske Kancelli, kan selve Kancellipræsidenten ikke finde noget om denne Sag. Og det er dog ikke noget ganske ligegyldigt Aktstykke. Skrevet i Falcks rolige, men fastformede Sprog fremfører den i kraftige Vendinger Ønsket om, at den daværende Forfatningskommission for Hertugdømmet Holsten maa blive forøget med Mænd fra Slesvig, og at en fornyet og forbedret Stænderforfatning snart maa træde i Virksomhed. Den er underskrevet af 150 Mænd, saa vel Godsbesiddere og Godsforpagtere som Borgere baade fra Slesvig og Holsten, tildels under Omslaget i Kiel, og afsendt til København af den ivrigt liberale Læge Franz Hegewisch, Lornsens mest trofaste og uegennyttige Ven i Aarene efter $1830^{2}$.

Efter Chr. Paulsens egen ovennævnte Fremstilling i Dagbogen er der tre Synspunkter, der har hindret ham $\mathrm{i}$ at slutte sig til Lornsen. For det første, som allerede nævnt, Hensynet til "vor gode Konges Personlighed", og for det andet - og her var det, at Falcks Ord virkede afklarende paa Paulsens Standpunkt - den Opfattelse, at Tidspunktet var uheldigt valgt „i dette Øjeblik, da ingen ny indvortes Grund" „for de lidenskabelige Ønsker og for de hæftige Skridt" var til Stede „og Nøden i Landet fraraadte enhver Folkebevægelse" ${ }^{3}$. Det hensynsløst fremstormende hos Lornsen, hans nordiske Bersærkernatur 4, har virket skræmmende paa den hensynsfulde Paulsen som paa den besindige Falck, begge af Natur som af Profession lovlydige Mænd.

Hvis Chr. Paulsens Ord skal staa til Troende, har han i Vidners Nærværelse aftvunget Lornsen den aabne Bekendelse, at Vold stod som det sidste Middel i Baggrunden for hans Plan ${ }^{5}$. Naar Jansen ikke kan bringe denne Udtalelse i Samklang med Paulsens Vidneforklaring i Lornsensagen i Følge Procesakterne, hvor han nemlig udtaler, at Lornsen, skønt Drøftelsen blev heftig, „ikke skulde have talt om noget andet Middel [til at opnaa sin Hensigt] end Petitioner, navnlig ikke om Anvendelse af Vold" ", er det forstaaeligt nok. Paa det samme

1 Paul Richter: Anf. Sted, S. 498-499 (og Anm. I). 2 Om Franz Hermann Hegewisch jvf. Afh. om U. J. Lornsen, S. 49, Note 3. ' Livshistorien, S. 18. 4 Caroline Hegewisch i et Brev Jan. I831. Caroline Hegewisch: Auszüge aus ihren Briefen ... Trykt som Manuskript. Kiel 1882. S. 63, jvf. S. 62. 5 Livshistorien, S. 18. Samtalen har fundet Sted Søndag d. 7. Nov. 1830, en Uge før Dagbogsoptegnelsen er skrevet. 'K. Jansen: Nachtrag zu U. J. Lornsen. Zeitschrift Bd. 3. (1873), S. 396 . 
Grundlag mener K. Alnor ${ }^{1}$ at kunne frikende Lornsen for at have næret Planer om Vold, medens K. Th. Strasser, omend ikke just ud fra Paulsens Beretning, paa det bestemteste hævder, at det karakteristiske for Lornsen i Modsætning til hans Forgængere og de fleste af hans Samtidige blandt de Liberale, er, at han er fuldt og fast overbevist om, at Magtanvendelse i det politiske Liv er et ganske nødvendigt Middel. Strasser vil endda vide, at Lornsen i Følge Procesakterne har tænkt baade paa et bevæbnet Oprør og paa Dannelse af Kommunalgarder ${ }^{2}$.

Den tilsyneladende Modsigelse i Paulsens Udtalelser opklares uden større Vanskelighed ved Dagbogens Hjælp. Under Søndag d. 27. Febr. r83i har Paulsen indført en Beretning om sin Vidneforklaring for Undersøgelseskommissionen en Ugestid før. Han skriver her: „Min mærkværdige Samtale med Lornsen var da Hovedgjenstanden for Afhørelsen ...; men som Vidne turde jeg naturligvis kun udsige det mig bestemt af ham Meddeelte og om en af ham fattet Plan til at bruge Vold kunde jeg derfor ikke tale".

Det vil altsaa sige, at da Lornsen ikke har meddelt Paulsen nogen som helst Enkeltheder i Forbindelse med en Plan om at bruge Vold, men kun i Almindelighed indrømmet, at Forfatningskravet skulde gennemføres, om fornødent ogsaa med Anvendelse af Vold, saa skønner Paulsen, at en Fremdragelse af disse Ord i Retten vil være uden mindste positive juridiske Betydning for Bedømmelsen af Lornsens større eller mindre Grad af Strafskyldighed, men langt snarere faa Karakteren af upaakrævet Angiveri. Man maa jo vel gøre sig klart, at det kun er sin Dagbog, Paulsen betror de farlige Ord om Vold, og at han næppe har næret mindste Ønske om at styrte Lornsen dybere i Ulykke, end Lornsen selv havde bragt sig.

Har Lornsen da mon for Alvor i Novemberdagene 1830 haft Planer om at bruge Vold, at fremkalde Oprør? Efter alt, hvad der foreligger, kan man vanskeligt forestille sig, at Lornsen skulde have tænkt sig stort mere ved disse Ord end O. Lehmann i 1848 ved Udtrykket „Fortvivlelsens Selvhjælp“. I begge Tilfælde har de bevægede Forhold og den indre Spænding affødt de stærke Ord, uden at der i Bevidstheden har været nogen klart udformet Plan, som svarede dertil. Senere, efter Fængselstiden, kommer det til at staa klart for Lornsen, at uden Anvendelse af Magtmidler, ja Blodsudgydelse, ${ }^{3}$ kan Frihedens Sag ikke gennemføres. Hver paa sin Vis har da baade Alnor og Strasser Ret.

1 K. Alnor: Uwe Jens Lornsen. Eine historisch-politische Skizze. Zeitschrift, Bd. 54. (1924), S. 422. 2 K.Th. Strasser: Uwe Jens Lornsen, der Demagoge. Preussische Jahrbücher, Bd. I91. (Jan.-Marts I923), S. 345. ' Volquart Pauls: Uwe Jens Lornsens Briefe an Franz Hermann Hegewisch. Schleswig 1925, S. 122, I33, I50. 
Og saa er der endelig det tredje Punkt, hvor Paulsen ved Gennemlæsning af Lornsens Pjece har følt sig nødsaget til at fremkomme med en bestemt Indsigelse. „Jeg gjorde ham endvidere opmærksom derpaa, at han aldeles ikke havde agtet Slesvigs og Holstens forskjellige Forhold, at Kongen af Danmark aldrig kunde tilstede Slesvigs fuldkomne Adskillelse fra Danmark og Sammensmeltning med Holsten. “

Et med fæl Lidenskab udtalt: „Alte geschichtliche Verhältnisse gehen uns nicht an, wir wollen es nun so; jede Zeit soll sich ihren Zustand bilden, ich setze Alles daran “, var Svaret".

Som i et skærende Glimt belyses her det historiske Møde ikke blot mellem de to Slesvigere, som banede Vej for den tyske og den danske Nationalitetsbevægelse inden for deres fælles Hjemstavn, men lige saa fuldt mellem Repræsentanterne for to modsat rettede, politisk-farvede Livsopfattelser, der den Dag i Dag kæmper med hinanden om Overtaget.

Med U. J. Lornsens Fremtræden finder det moderne Gennembrud Sted i Danmark paa det politiske Omraade. Med sin Foragt for de „gamle historiske Forhold “, baade for gamle Privilegier og for uskrevne Traditioner, for den tilvante Blanding af Underdanighed og Hengivenhed for Kongen og Respekt for ens Overordnede som for alle de andre utallige Hensyn til Folk og Forhold, der indsnævrede den enkeltes Handlefrihed og kun levnede ham Plads til at „lære sin egen Lektion" ${ }^{2}$ uden at bekymre sig om de andres, er Lornsen en ganske moderne Aand. Og hans Synspunkt, at det er den nulevende Slægts øjeblikkelige Tarv set i Lyset af Trangen til dens Fremtidsudvikling, der skal være enebestemmende for Indretningen af Statsstyrelsen, havde vel nok $i$ vore Dage større Mulighed for at gøre sig gældende, end da han udsendte sit Skrift.

Over for ham staar nu Chr. Paulsen ganske vist ogsaa som Fremskridtsmand, men som den, der vil knytte det nye til det gamle, bygge paa de gamle Traditioner og undgaa et Brud $\mathrm{i}$ den historiske Udvikling ${ }^{3}$.

Det lader til, at Lornsen har kunnet tage sin juridiske Eksamen i Kiel uden at Falcks og Dahlmanns Virksomhed, deres Forelæsninger saa lidt som deres Tidsskriftartikler har gjort mindste Indtryk paa ham. Naar han i Fængselstiden

${ }^{1}$ Livshistorien, S. I9. ${ }^{2}$ [Pastor Vent, Hademarschen]: Worte der Beruhigung und Ermunterung an das Volk. Schleswig 1830, S. 24. - Overbibliothekar Cramer, Kiel: Ein Wort an Freunde und Bekannte ... r830, S. 13. - Jvf. K. Jansen: U. J. Lornsen, henholdsvis S. 264 og 265 f. 3 Jvf. Th. Graae: U. J. Lornsen, S. I49. ' $\mathrm{K}$. Jansen: Anf. Værk, S. 173. Han har i Kiel, da han indstiller sig til Eksamen, hverken hørt Forelæsninger over Verdens- eller Fædrelandshistorie, hjemlig Ret, tysk Privatret eller Retshistorie. 
og de sidste Aar af sit Liv kaster sig over de "gamle historiske Forhold“, som i November 1830 ikke har Gnist af Interesse for ham, saa er det ingenlunde af Kærlighed til historisk Forskning eller for selv at naa til Klarhed over Maal og Midler, nej, han mener, at „hvad hver Generation erkender og erklærer for hensigtsmæssigt, lad det saa afvige nok saa meget fra det bestaaende, det er historisk og intet Spring " 1 og han protestererer udtrykkeligt mod at gaa frem Skridt for Skridt ved at knytte det nye til det bestaaende, saadan som Historikerne (blandt Frihedsvennerne) ønsker det. Ja, for ham selv personligt betyder det historisk givne saa lidt, at han kan udbryde: „Jeg er nu ganske vist af den Mening, at selv om Historien vilde have leveret et modsat Resultat, vilde vore Krav dog alligevel ikke være mindre velbegrundede, eftersom de jo udspringer af Sagens Natur“ 2.

Han slider sig kun gennem de indviklede statsretlige Udredninger og tunge historiske Fremstillinger, „fordi det større Publikum lægger mere Vægt paa den historiske Ret, end man sædvanligvis antager", og fordi disse samme brede Lag handler mere tillidsfuldt ud fra Bevidstheden om at have den historiske Ret paa deres Side, end hvis de maa indrømme over for sig selv, at de kun stræber efter de ønskede Maal, fordi det nu engang passer dem$^{3}$.

Med andre Ord: Lornsen har intet tilovers for den historiske Skole i Videnskab saa lidt som i Politik. Han vender sig kun til de historiske Studier, fordi han i I 830 har gjort den bitre Erfaring, at uden Bevisgrunde hentede fra Historien kan han ikke klare sig i Diskussionen med de Mænd, der behersker den offentlige Mening i Landet, og hvis ikke han kan fremføre de historiske Retskrav i populær Form, saa kan han ikke vinde den nødvendige Tilslutning hos de brede Lag af Befolkningen.

I sin Pjece I830 anfører U. J. Lornsen som Bevis for, at hans Krav er berettigede, kun, at de stemmer med „,indsigtsfulde Landsmænds Overbevisning “4, og Tanken om en Adskillelse af de to Hertugdømmer i forfatningsmæssig Henseende fejer han flot til Side uden anden Begrundelse end den, at noget saadant er „simpelthen utænkeligt for enhver Slesvigholstener" 5 .

Men allerede Sommeren I 83 I tegner det sig saa heldigt for ham, at han mener at kunne slaa fast, at det, „som vi gør Krav paa, nemlig en fælles Repræsentativforfatning for begge Hertugdømmer er fuldkommen begrundet i Historien og Hertugdømmernes Rettigheder" *.

1 Volquart Pauls: Anf. Værk, S. 34 (Nr. 15, 8/. [193I]). ${ }^{2}$ Anf. Værk, S. 23 (Nr. ro, [Juni el. Juli 1831]). ${ }^{3}$ Anf. Sted. 4 Ueber das Verfassungswerk in Schleswigholstein. Kiel r83o, S. 6. Anf. Sted, S. 4. B Breve til Hegewisch, S. 22 (Nr. 10). 
Og et halvt Aar senere gentager han den samme Paastand udførligere: „.. .den Stilling, som vi maa tilstræbe for Hertugdømmerne inden for det danske Statsforbund, dersom vi vil lade Landets Vel og Folkets Ere og Værdighed være vor Rettesnor, nemlig Forbundsforholdet, som det [ganske] kort er udtalt i min lille Pjece, det er tillige den [Stilling], hvorpaa vi i Følge Historien har et fuldkommen begrundet Retskrav, hvorefter vor Historie bestandig har kæmpet, som den ogsaa har naaet og ikke paa ny opgivet"1.

I det Sæt af Tanker, som ligger til Grund for Lornsens Pjece, er en af de væsentligste Forudsætninger den, at Slesvigholstenerne (d. v. s. alle Beboerne $i$ de to Hertugdømmer) og Danskerne er to forskellige Folk, som i Øjeblikket paa Grund af den kraftesløse og ubehjælpsomme (unbehü(l)fliche?) administrative Forbindelse ligner et sammenvokset Tvillingpar ${ }^{2}$.

Om en fuldstændig Sammensmeltning gennem en Danisering kan der ikke være Tale; ethvert Forsøg i den Retning vil blive vist eftertrykkeligt tilbage fra tysk Side. Lornsen kræver tværtimod en fuldstændig Adskillelse af Hertugdømmernes Administration fra Kongeriget, saa at hver af de to Tvillingbrødre kan faa sin egen frie, selvstændige Udvikling og med Kongen i Spidsen gaa Fremtiden imøde. Fælles Konge og fælles Fjende skulde da blive de eneste, men efter hans Mening ogsaa fuldt tilstrækkelige Baand, der binder dem sammen ${ }^{3}$.

I dette Syn paa Hertugdømmernes Stilling til hinanden og over for Kongeriget faar Lornsen Tilslutning fra det yngre Slægtled af slesvig-holstenske Jurister og Historikere i de Indlæg i Form af Pjecer, der snart myldrer frem.

Advokat Beseler ${ }^{4}$ betoner stærkt Lornsens Ord om, at en Adskillelse af Hertugdømmerne er simpelthen utænkelig for enhver Slesvigholstener; den vilde vække den dybeste Sorg, mens en nøjere Forbindelse af Hertugdømmerne med Kongeriget ingen Lykke vilde bringe, fordi de to Parter var for grundforskellige. Advokat Bremer ${ }^{5}$ fremhæver det historisk begrundede Retskrav paa en fælles Stænderforsamling for Hertugdømmerne, mens U.J. Lornsens nære Medarbejder under Drøftelserne og Agitationen i Kiel, Professor A. L. J. Michelsen ${ }^{6}$

1 Anf. Værk, S. 48 f. (Nr. 22, ${ }^{20} / 11$ 1831). ${ }^{2}$ Anf. Sted, S. I I. ${ }^{3}$ Anf. Sted, S. Io f. 4 Ein Schleswiger [W. Beseler]: Beleuchtung der Brochure: Einige Worte über ... [Lornsens Skrift]. Leipzig 1830, S. 12 ff. - Jvf. K. Jansen: U. J. Lornsen, S. 255 f.; Th. Graae: U. J. Lornsen, S. I40 f. 'J. Bremer: Ueber den Verfall und die Wiederherstellung der landständischen Freiheit in Schleswig-Holstein. Braunschweig 1831. Jvf. Jansen: Anf. Værk, S. 273 f.; Th. Graae: Anf. Værk, S. 143. ' Ein Schleswig-Holsteiner. [A. L. J. Michelsen]: Sendschreiben an Herrn Dr. C. F. von Schmidt-Phiseldeck ... betreffend das Verfassungswerk in Schleswig-Holstein. Hamburg 1831 , S. 8. Jvf. Jansen, S. 272 f.; Graae:

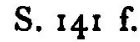


slaar paa, at Ophævelsen af Slesvig-Holstens Enhed vilde krænke baade Holstenernes og Slesvigernes Nationalfølelse paa det dybeste.

Syndikus Klenze, Uetersen ${ }^{1}$, der iøvrigt imødegaar alt det i Lornsens Pjece, der kunde pege i Retning af en Sønderlemmelse af Staten, og lige saa lidt vil høre Tale om en Adskillelse som om en Sammensmeltning af Hertugdømmerne og Kongeriget ${ }^{2}$, giver i meget stærke Ord Udtryk for Slesvig-Holstens Samhørighed. Slesvig og Holsten, siger han, er ved Sprog(!), Familieforbindelser, Handel og Repræsentanterne for den højere Intelligens (gennem Landsuniversitetet $\mathrm{i}$ Kiel) saa sammenflettede og sammenvoksede, at de ikke kan skilles. De er eet Liv, een $\mathrm{Sj}^{3} \mathrm{l}^{3}$.

Paa den anden Side er det ikke blot Skribenter fra Kongeriget ${ }^{4}$, der gør Indsigelse mod, at Slesvig og Holsten betragtes som eet, uanset afvigende statsretlige og sproglige Forhold; men ogsaa fra Hertugdømmerne selv lyder Protester herimod.

Hvor meget man skal lægge ind i Arnæs-Præsten Wilh. Thiess's „Wir Schleswig-Dänen " 5 , kan være ret tvivlsomt. Hans Skrift har ikke nationalt, men religiøst Sigte. Wit v. Dörring ${ }^{6}$ bebrejder Lornsen, at han puster til Hadet mellem Danske og Tyske og vil gøre Slesvig til en Provins af et drømt Tyskland. Det samme slaar U.v. Brockdorff ${ }^{7}$ paa og nævner tillige imod Lornsens Betragtninger, at i den større Halvdel af Slesvig tales der Dansk, saa at Slesvig snarere skulde forbindes med Danmark end med Holsten, hvis man lagde de sproglige Forhold til Grund for Afgørelsen ${ }^{8}$. En fuldstændig Sammensmeltning af Slesvig med Holsten til en Stat for sig vilde derimod let kunne give Anledning til de samme Kla-

1 Syndikus Klenze in Uetersen: Ueber das Verfassungswerk in Schleswig-Holstein, eine Beleuchtung. Altona 1830 . Jvf. Jansen, S. 26r f.; Graae: S. 143 f. ${ }^{2}$ Anf. Skrift, S. $3^{8}$ f. ${ }^{3}$ Anf. Skrift, S. 4I. ${ }^{4}$ I. C. Lausen: Beleuchtung der irrigen Ansichten einiger Holsteiner über das sogenannte schl.-holst. Verfassungswerk. Kbh. I83 I. Forfatteren hævder, at Sproget ned til Husum og Slien er dansk, og at kun ca. 50 Ord afviger fra det øvrige danske Sprog; kun er Accenten og Udtalen af Selvlydene anderledes end $i$ Nørrejylland. $2 / 3$ af Slesvigerne taler altsaa Dansk. Stednavnene er næsten alle danske. Jvf. Graae, S. I40. - C. F. v. Schmidt-Phiseldeck: Ueber die neuerlichen Aufregungen in den Herzogthümern Schleswig und Holstein. Kbh. I83o. Der fremhæves (S. I3 f.), at Slesvig aldrig har hørt til Tyskland. Jvf. Jansen, S. 270 f.; Graae: S. I39. 5 Wilh. Thiess: Arzenei wider das Revoluzions-Fieber. Schleswig 1830, S. 14. Skriftet er ogsaa oversat paa Dansk af J. P. Rasbech. Kbh. 1830, der i Tilknytning til dette Udtryk giver en udførlig Note om Slesvigs og Slesvigernes Stilling inden for Monarkiet. Jvf. Jansen, S. $263 \mathrm{f}$. 6 Wit von Dörring: Was uns Noth thut! Hamburg 1831, S. 27. Jvf. Jansen, S. 274 f.; Graae, S. 136. 7 U. Frhn. von Brockdorff: Betrachtungen veranlasst durch die Schrift des Herrn Kanzleiraths Lornsen .. Schleswig 1830, S. 7. Jvf. Jansen, S. 259 f.; Graae, S. 137 f. 8 Anf. Skrift, S. 8. 
ger, som Belgierne anførte mod Holland, at man vilde forene to Folk med hinanden, der hvad Oprindelse og Sprog angik, var ganske forskellige ${ }^{1}$.

De slesvig-holstenske statsretlige Teorier, som de i Hovedsagen allerede tidligere var udformede af Dahlmann ${ }^{2}$ og Falck, blev som før nævnt fremført i ret sammentrængt og overskuelig Form af Advokat Bremer, men tillige af Lornsens nære Venner, Lægen paa Sild G. N. Wülfke ${ }^{3}$ og Professor Michelsen ${ }^{4}$.

Mod disse Skrifter vender den halvt tyskfødte og tyskuddannede, men ivrigt dansksindede Herredsfoged G. v. Wimpfen sig i en historisk-statsretlig Undersøgelse ${ }^{5}$, hvorved han bl. a. mener at kunne fastslaa, at der ikke eksisterede noget gyldigt Retskrav, hvorved man vilde kunne begrunde Ønsket om en forfatningsmæssig Forbindelse mellem Slesvig og Holsten, og at en saadan Forbindelse iøvrigt heller ikke vilde stemme med Hertugdømmet Slesvigs Interesser ${ }^{6}$. Men Wimpfens Bevisførelse, der frembød nogle saarbare Punkter, blev straks efter tilbagevist af Falck ${ }^{7}$, for hvis Autoritet som retshistorisk Forsker de fleste bøjede sig uden nærmere selvstændig Prøvelse. Den rent statsretlige Drøftelse var endnu paa dette Tidspunkt ikke egnet til at sætte Sindene i dybere Bevægelse. Det er ogsaa fra et ganske andet Synspunkt, at Grundtvig, i det ejendommeligste af alle de mange Indlæg i Striden, tager Spørgsmaalet Danmark og Holsten (og Slesvigs usikre Mellemstilling) op til Behandling ${ }^{8}$.

Grundtvigs Udgangspunkt for Forstaaelsen af det, der begynder at røre sig herhjemme, er hans intuitive Fornemmelse af, hvordan „Folke-Aanderne i Europa“ vaagner "efter en lang Slummer og staae enten op med forklarede Legemer, eller gaa igien i Skygge-Hamme og giør da stor natlig Uro i deres gamle Hjem-Stavne" 9 , altsaa af det 19 . Aarhundredes langsomt vaagnende Nationalitetsbevægelser. Lige saa stærkt han føler, at han ikke for alt $i$ Verden vilde eller kunde gaa ud af sit gode Skind og blive en Tysker, lige saa lidt vil

1 Anf. Skrift, S. 8 f. $\quad 2$ Nyere Litteratur om Dahlmann: Jvf. Afhandlingen om U.J.Lornsen, S. 57, Note 3. ' [G. N. Wülfke]: Zur Würdigung des Strebens nach Verfassung in SchleswigHolstein. Deutschland, Nov. 1830. Jvf. Jansen, S. 267 f.; Graae, S. 143. A. L. J. Michelsen: Ueber die vormalige Landesvertretung in Schleswig-Holstein. Hamburg 183I. Jvf. Graae, S. I4I f. 5 C. von Wimpfen: Ueber die staatsrechtlichen Verhältnisse der Herzogthümer Schleswig und Holstein. Kiel 183r. Jvf. Jansen, S. 274; Graae, S. I45 f. ' C. v. Wimpfen: Anf. Skrift, S. 39. 7 N. Falck: Handbuch des schlesw.-holst. Privatrechts. II, Altona I831. Vorrede, V ff. Jvf. Graae, S. 146 f. - Chr. Paulsen: Samlede Skrifter II, S. 359, Note 3 . 8 Nik. Fred. Sev. Grundtvig: Politiske Betragtninger med Blik paa Danmark og Holsteen. Kbh. 1831, IV. Om Danmark og Holsteen, S. $5^{6}$ ff. Jvf. Jansen, S. 275 ff.; Graae, S. $5^{6}$ f. Endvidere K. Fabricius: Folkenes Forbund og N. F.S. Grundtvig, Gads danske Magasin, 15. Aarg., 1921, S. 353 ff. ' Grundtvig: Anf. Skrift, S. 59 . 
han forlange nogen Tysker til at blive Dansk ${ }^{1}$. Og han fortænker ikke Holstenerne $i$, at de bestemt frabeder sig en Sammensmeltning med Danmark, om den saa aldrig saa meget kan synes at være til deres eget Bedste ${ }^{2}$; thi „Sprog-Forskiel er et Skille-Rum, ingen Menneske-Haand har opført, og derfor heller ingen Menneske-Haand kan nedrive, men lettelig fortage sig paa "3.

Mens Grundtvig saaledes ikke er i Tvivl om, hvad han skal mene om Holstenerne og deres Krav, nemlig at de virkelig er „opsatte paa at faae en standsmæssig Forfatning, og at have saa lidt som mueligt med Danmark at skifte", og at Kongen sagtens snart vil opfylde i hvert Fald en Del af deres Ønsker ${ }^{4}$, er han anderledes usikker over for Slesvig. Allerede dets Dobbeltnavn „Slesvig eller Sønder-Jylland“ „klinger lidt tvivlsomt og tvetydigt" ${ }^{\text { }}$ i hans Ører, og hvad enten man „raadfører sig med Folkesproget eller med Historien, immer faar Man det dobbelte, eller tvivlsomme og tvetydige Svar, som ligger i Navnet" ${ }^{\text {" }}$. Da Grundtvig nu indser, at det næppe længere gaar an, som de danske Konger hidtil har gjort, at lade Slesvig blive staaende i denne uklare Mellemstilling og skyde Afgørelsen af, hvor det skal høre hen, ud i en uvis Fremtid, saa finder han det „naturligst at lade Slesvig eller Sønder-Jylland sige, til hvilken Side det helst gad hørt, thi Selvgjort er Velgjort og Man finder sig bedst $\mathrm{i}$ at ligge, som Man selv har redt, om det end i Grunden er daarligere gjort end Man ellers kunde havt det. " Det er ikke just nogen Folkeafstemning Grundtvig tænker paa; nej, i Overensstemmelse med hans daværende Syn paa Forfatningsspørgsmaalet afskyer han al den Slags og ønsker i Stedet, at „den Danske Regiering, efter god gammel Vane, foranledigede de Slesvigere, der har lært at skrive, til under deres Navn paa Prænt, at sige deres Mening kiønt, hvis de havde nogen, om det, i vor lille Verden, vigtige Spørgsmaal: enten Slesvig helst vil have Lands-Fader tilfælles med os, eller Konge-Hertug med Holsteen ? " 7 Hvad Slesvigerne vil svare paa dette Spørgsmaal, skal Grundtvig lade være usagt; men han formoder dog stærkt, „at Slesvigerne vilde føle sig Kongen mest forbundne, naar Han vilde forbinde dem med Holsteen " ${ }^{8}$. Og naar Grundtvig skal angive, hvorpaa han bygger denne Formodning om, at Slesvigerne vil vælge Forbindelsen med Holsten, saa anfører han, foruden den gejstlige og verdslige Sammenhæng, „der altid har været mellem Hertugdømmerne, og er endnu“, „at alle de Slesvigere, jeg har

1 Anf. Sted, S. $57 . \quad 2$ Anf. Sted, S. 58. $\quad 3$ Anf. Sted, S. 57. ' Anf. Sted, S. 61. ${ }^{5}$ Anf. Sted, S. 59. 'Anf. Sted, S. 6o. 7 Anf. Sted, S. 6o f. 8 Anf. Sted, S. 62. Udtalelsen hos K. Fabricius: „Folkenes Forbund og N. F. S. Grundtvig“, Anf. Sted, S. 354: „Paa Forhaand tror Grundtvig, at Sønderjylland vil valge det første Alternativ", maa vel bero paa en Fejlskrivning. Jvf. det efterfølgende. 
mødt, eller hørt Tale om, havde, efter deres eget Sigende, hjemme i Holsteen, og naar de frittedes nøiere, dog altid i Dansk Holsteen ", og som det tredje, at de, der har Lyst til at faa „en standsmæssig Forfatning“, ikke kan vente at opnaa den $\mathbf{i}$ Forening med Danmark, der frivilligt har givet sig ind under det enevældige Styre og efter Grundtvigs Mening nødigt skulde fortryde saa klog en Beslutning 1 .

Saa lidt kendte altsaa den Mand i Danmark, der havde det skarpeste Blik for de nationale Spørgsmaal, til, hvad Sønderjylland gemte bag sit officielle, tyskprægede Ansigt, saa sløret og fjernt stod Mennesker og Forhold i „Dansk Holsteen " selv for den, der mest vaagent spejdede efter, hvad der rørte sig i Folkebevidstheden. Eller rettere, saa ubestemmelige og ufærdige var Trækkene $i$ Sønderjyllands Ansigt endnu, at ikke engang den, der dog besad en vis Evne til at læse ud i Fremtiden, kunde raade, hvad Skæbne der ventede det skønne, ombejlede Land.

Først gennem Chr. Paulsens Skrift traadte det danske Sønderjylland frem for den kongerigske som for den slesvigholstenske, ja, for selve den sønderjydske, Bevidsthed med sit eget Ansigt. Vidste man ikke bedre, kunde man fristes til at tro, at det var Grundtvig, som havde manet det frem med sin Opfordring til Slesvig om at slaa Sløret til Side, saa man kunde se det ind i Øjnene.

Thi vel var der før skrevet af andre om Sønderjyllands skiftende Skæbne og nuværende statsretlige Stilling, ogsaa om Sproget, dets Herkomst og Udbredelse og Vigen tilbage for Kultursproget sydfra; men saa levende og indtrængende, af en, man umiddelbart følte havde Ret til at tale med, fordi denne Bostavn var hans, og fordi han elskede den højt, havde endnu ingen kunnet føre Ordet paa Danskhedens Vegne. Det er Chr. Paulsens uvisnelige Fortjeneste, at han tog Opgaven op, sagtmodigt, men varmt og fast, paa en Tid, da ingen anden havde Vilje og Evne dertil, og med nænsom Haand samlede alle de smaa Træk sammen til et Billede af det danske Sønderjylland, som hans jævne Landsmænd vilde kendes ved og kunde hente Styrke og Fortrøstning af.

1 Grundtvig, Anf. Sted, S. 62. 